\title{
Review \\ Recent Advances in Fiber-Hydrogel Composites for Wound Healing and Drug Delivery Systems
}

\author{
Marta O. Teixeira, Joana C. Antunes (D) and Helena P. Felgueiras *(D) \\ Centre for Textile Science and Technology (2C2T), Department of Textile Engineering, University of Minho, \\ Campus of Azurém, 4800-058 Guimarães, Portugal; martasofia.teixeira@hotmail.com (M.O.T.); \\ joana.antunes@2c2t.uminho.pt (J.C.A.) \\ * Correspondence: helena.felgueiras@2c2t.uminho.pt; Tel.: +351-253-510-283; Fax: +351-253-510-293
}

check for updates

Citation: Teixeira, M.O.; Antunes, J.C.; Felgueiras, H.P. Recent Advances in Fiber-Hydrogel Composites for Wound Healing and Drug Delivery Systems. Antibiotics 2021, 10, 248. https: / / doi.org/10.3390/ antibiotics 10030248

Academic Editor: Serena Riela

Received: 29 January 2021

Accepted: 25 February 2021

Published: 2 March 2021

Publisher's Note: MDPI stays neutral with regard to jurisdictional claims in published maps and institutional affiliations.

Copyright: (C) 2021 by the authors. Licensee MDPI, Basel, Switzerland. This article is an open access article distributed under the terms and conditions of the Creative Commons Attribution (CC BY) license (https:// creativecommons.org/licenses/by/ $4.0 /)$.

\begin{abstract}
In the last decades, much research has been done to fasten wound healing and target-direct drug delivery. Hydrogel-based scaffolds have been a recurrent solution in both cases, with some reaching already the market, even though their mechanical stability remains a challenge. To overcome this limitation, reinforcement of hydrogels with fibers has been explored. The structural resemblance of fiber-hydrogel composites to natural tissues has been a driving force for the optimization and exploration of these systems in biomedicine. Indeed, the combination of hydrogel-forming techniques and fiber spinning approaches has been crucial in the development of scaffolding systems with improved mechanical strength and medicinal properties. In this review, a comprehensive overview of the recently developed fiber-hydrogel composite strategies for wound healing and drug delivery is provided. The methodologies employed in fiber and hydrogel formation are also highlighted, together with the most compatible polymer combinations, as well as drug incorporation approaches creating stimuli-sensitive and triggered drug release towards an enhanced host response.
\end{abstract}

Keywords: fiber-hydrogel composite; biodegradable polymers; skin regeneration; drug delivery platforms; controlled release

\section{Introduction}

Biomaterials are defined as nonviable materials, with potential for applications in medical devices, that possess the ability to interact with biological systems to evaluate, treat, replace or enhance the performance of any tissue [1]. Biomaterials are classified in different ways; the most common refers to their chemical nature and is subdivided in metallic materials (ferrous and non244-ferrous) and non-metallic materials (organic: polymers, biological materials, and carbons; and inorganic: ceramics and glasses). Composites are considered another very important class of biomaterials and result from the combination of two classes of materials that work in synergy to improve the properties of the final product above those of the individual components [1,2].

The continued research in this field has raised the specificity level of the biomaterials developed and, therefore, has increased its impact in the healthcare global market [1]. Polymers represent a large portion of all biomaterials used in the biomedical field (about $45 \%$ ) [2], and their application appears to have no end. They can be processed in the form of particles, foams, films, membranes, hydrogels and fibers, and combinations of these 3D structures can then be made to generated intricate, target-direct, specialized biomedical systems. Biomedicine has resorted to these constructs to understand specific biological processes and to engineer high-performance therapies to treat a variety of diseases. The need to match the desired functions / characteristics of a given tissue or cell has driven the combination of different classes of biomaterials in complex constructs (e.g., fiber-hydrogel composite) that can effectively respond to the local demands and provide the necessary tools to reach the desired goals. In recent years, fiber-hydrogel composites have been disclosed as one of those systems that combine different structures to improve individual 
features and enhance inherent advantages to achieve successful outcomes. In biomedical engineering, the importance of these constructs is particularly noticeable in wound healing and drug delivery. In both areas, fiber-hydrogel composites can be a good alternative to the use of antibiotics and/or their controlled administration.

The present review explores this subject further, starting with the introduction of basic concepts associated with polymer properties and processing in the form of fibers and hydrogels and then evolving towards the combination of these two structures in one to successfully respond to specific needs. The most recent studies highlighting fiber-hydrogel composites are here identified, giving particular attention to the engineering of wound dressings and drug delivery systems.

\section{Polymers Natural/Synthetic}

The word polymer is derived from the Greek poly and meros, meaning many and parts, respectively. Polymers are macromolecules that result from the repetition of smaller molecules, the monomers [3]. The nature of the monomers and the specific bonds generated between them, and their spatial rearrangement, determine the properties of the built polymer [4]. The process through which a polymer is formed is named polymerization and can be described as a chemical reaction in which the combination of one or more monomers occurs [3]. Polymers can also be biologically derived or synthetically produced [2]. Natural polymers are created in nature during the life cycles of biological systems, such as plants, microorganisms, and animals [5]. These polymers are widely used in scientific community, namely, in tissue engineering, wound dressing and drug delivery systems [6-8], due to their biocompatibility, non-toxicity, biodegradability and bioactivity, particularly their inherent anti-inflammatory and antibacterial properties [9]. These polymers include polysaccharides and polypeptides. Polysaccharides, the most abundant class of biopolymers, are polymeric carbohydrate molecules formed by glycosidic bonds with different structures and properties depending on molecular weight and chemical composition [8]. In particular, polysaccharides, compared to polypeptides, are generally more stable and usually do not denature on heating [10]. Regarding their chemical properties, they have polyfunctionality, high chemical reactivity, chirality, chelation and adsorption capacity, which allow them to be chemically and biochemically modified very easily. These modifications result in different polysaccharide derivatives, which increase the range of applications $[6,8,11]$. The alginate, hyaluronic acid (HA), cellulose and chitosan (CS) stand out between the polysaccharides for being the most used in biomedicine (Table 1). Just like polysaccharides, polypeptides are produced by microorganisms. Polypeptides are macromolecules composed of repeated units of amino acids linked by peptide bonds. Their versatility, flexibility, good performance in metabolic adaptation and imitation of the extracellular matrix makes them good candidates for tissue scaffolding and drug/gene delivery [12]. The most common polypeptides used in biomedicine are collagen and gelatin (Table 1). However, known limitations of natural polymers include their very low dimensional stability, susceptibility to immunogenic responses, possibility of pathogen transmission and high batch-to-batch variability $[12,13]$. For this reason, biodegradable synthetic polymers are frequently employed as alternatives.

Indeed, some of the key benefits of synthetic polymers are their reproducibility, which allows mass production, and their ability to be tuned according to specific requirements. Their degradation profile can also be easily manipulated via their hydrolytic groups [14], even though bulk degradation can occur [15]. Moreover, synthetic polymers are biologically inert, thus without a therapeutical impact, but may induce chronic inflammation [16]. In biomedicine, poly(ethylene oxide) (PEO), poly( $\varepsilon$-caprolactone) (PCL), polylactic acid (PLA), poly(lactic-co-glycolic acid) (PLGA), poly(vinylpyrrolidone)(PVP) and poly(vinyl alcohol) (PVA) $[15,17]$ constitute the most studied polymers in the field (Table 1) [18]. They may additionally be combined with natural polymers. Hybrid polymers can result from the total or part combination of natural and synthetic polymers. As is the case of the combination of the PLGA (synthetic polymer) and the CS (natural polymer) that result in the PLGA-CS 
hybrid polymer that has been studied in several areas, namely in therapeutic delivery [19]. The choice of polymers for the formation of scaffolds, based on their characteristics, has proved to be crucial in the properties and applicability of the final scaffold. Currently, synergisms between synthetic and natural biomaterials in the form of 3D scaffolds, such as hydrogels and nanofibrous mats, are in high demand for biomedical applications, being frequently preferred over constructs made of polymers belonging to only one of these categories $[7,15,20]$. 
Table 1. Origins and main properties of natural and synthetic polymers commonly used in wound healing, tissue engineering and drug delivery applications.

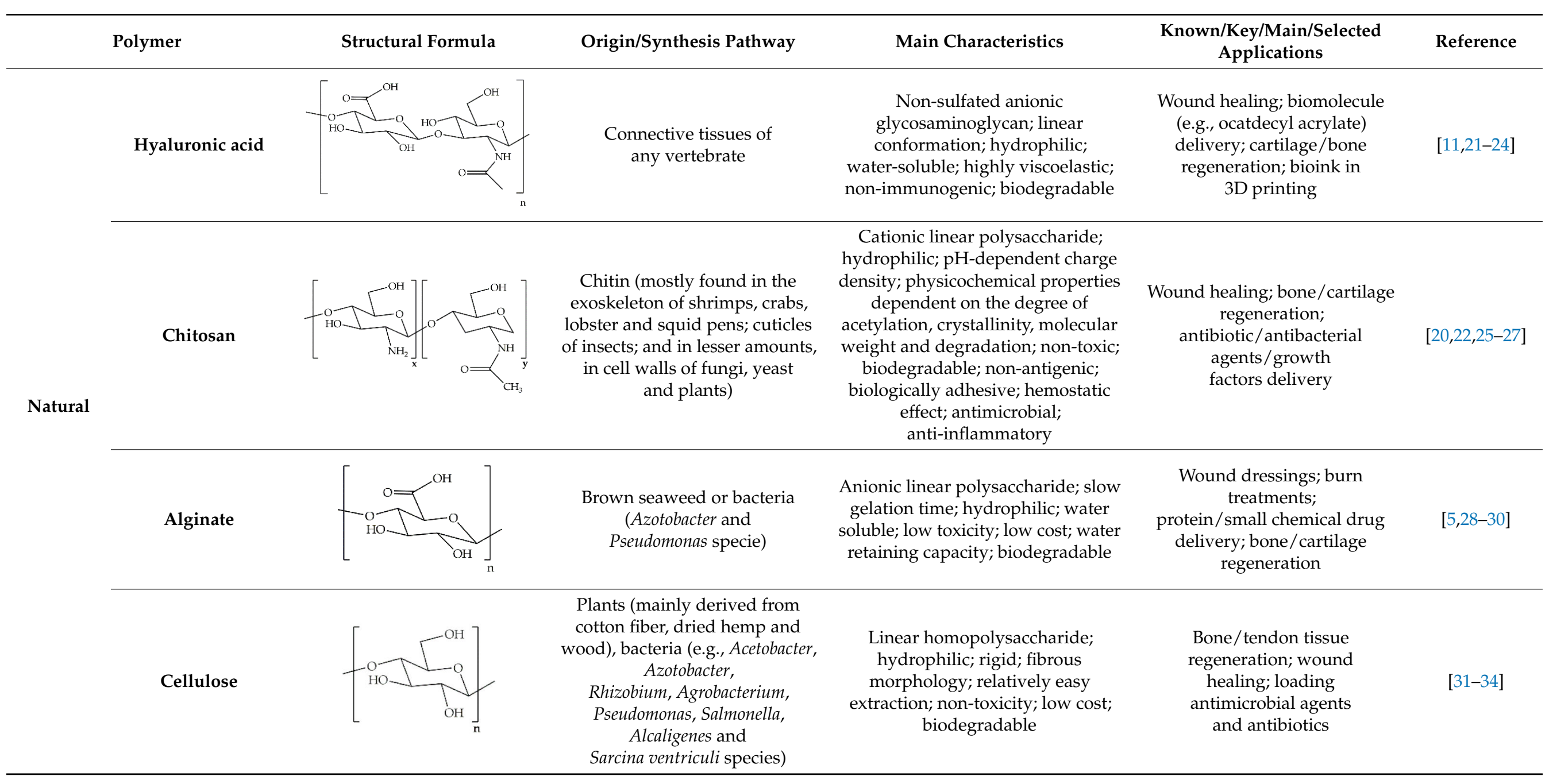


Table 1. Cont.

\begin{tabular}{|c|c|c|c|c|c|c|}
\hline & Polymer & Structural Formula & Origin/Synthesis Pathway & Main Characteristics & $\begin{array}{c}\text { Known/Key/Main/Selected } \\
\text { Applications }\end{array}$ & Reference \\
\hline Natural & Gelatin & & $\begin{array}{l}\text { Skin and bone of bovine and } \\
\text { porcine, fish and marine } \\
\text { organisms (incomplete } \\
\text { denaturalization of collagen) }\end{array}$ & $\begin{array}{l}\text { Linear polypeptide; hydrophilic; } \\
\text { water soluble }\left(35^{\circ} \mathrm{C}\right) \text {; soluble in } \\
\text { polyhydric alcohols and several } \\
\text { other organic solvents; cost efficient; } \\
\text { easily available; biodegradable; } \\
\text { non-antigenic; similarity to collagen }\end{array}$ & $\begin{array}{l}\text { Wound healing; bone } \\
\text { regeneration; articular cartilage } \\
\text { repair; tendon } \\
\text { tissue engineering }\end{array}$ & {$[26,35-37]$} \\
\hline \multirow{3}{*}{ Synthetic } & $\begin{array}{l}\text { Poly(ethylene } \\
\text { oxide) }\end{array}$ & & $\begin{array}{l}\text { Anionic ring-opening } \\
\text { polymerization of ethylene } \\
\text { oxide }(\mathrm{EO})\end{array}$ & $\begin{array}{l}\text { Neutral polymer; hydrophilic; } \\
\text { water soluble; low toxic; } \\
\text { biodegradable }\end{array}$ & $\begin{array}{l}\text { Gene/drug delivery systems; } \\
\text { biomedical implants; } \\
\text { neocartilage tissue formation; } \\
\text { transdermal delivery }\end{array}$ & [42-45] \\
\hline & $\begin{array}{l}\operatorname{Poly}(\varepsilon- \\
\text { caprolactone) }\end{array}$ & & $\begin{array}{l}\text { Ring-opening polymerization of } \\
\varepsilon \text {-caprolactone monomer using a } \\
\text { wide range of catalysts }\end{array}$ & $\begin{array}{l}\text { Semicrystalline; hydrophobic; } \\
\text { excellent mechanical strength; slow } \\
\text { degradation rate; nontoxic; } \\
\text { biodegradable }\end{array}$ & $\begin{array}{l}\text { Tendon tissue engineering; skin } \\
\text { regeneration; vascular scaffolds }\end{array}$ & {$[37,44,46,47]$} \\
\hline & Polylactic acid & $\mathrm{CH}_{3}$ & $\begin{array}{l}\text { Polycondensation of lactic acid } \\
\quad \text { and ring opening } \\
\text { polymerization of cyclic lactide }\end{array}$ & $\begin{array}{l}\text { Thermoplastic aliphatic polyester; } \\
\text { hydrophobic; poor ductility; low } \\
\text { strength; bioabsorbable; } \\
\text { biodegradable }\end{array}$ & $\begin{array}{l}\text { Ligament and tendon repair; } \\
\text { vascular stents; bone } \\
\text { regeneration }\end{array}$ & {$[5,48-50]$} \\
\hline
\end{tabular}


Table 1. Cont

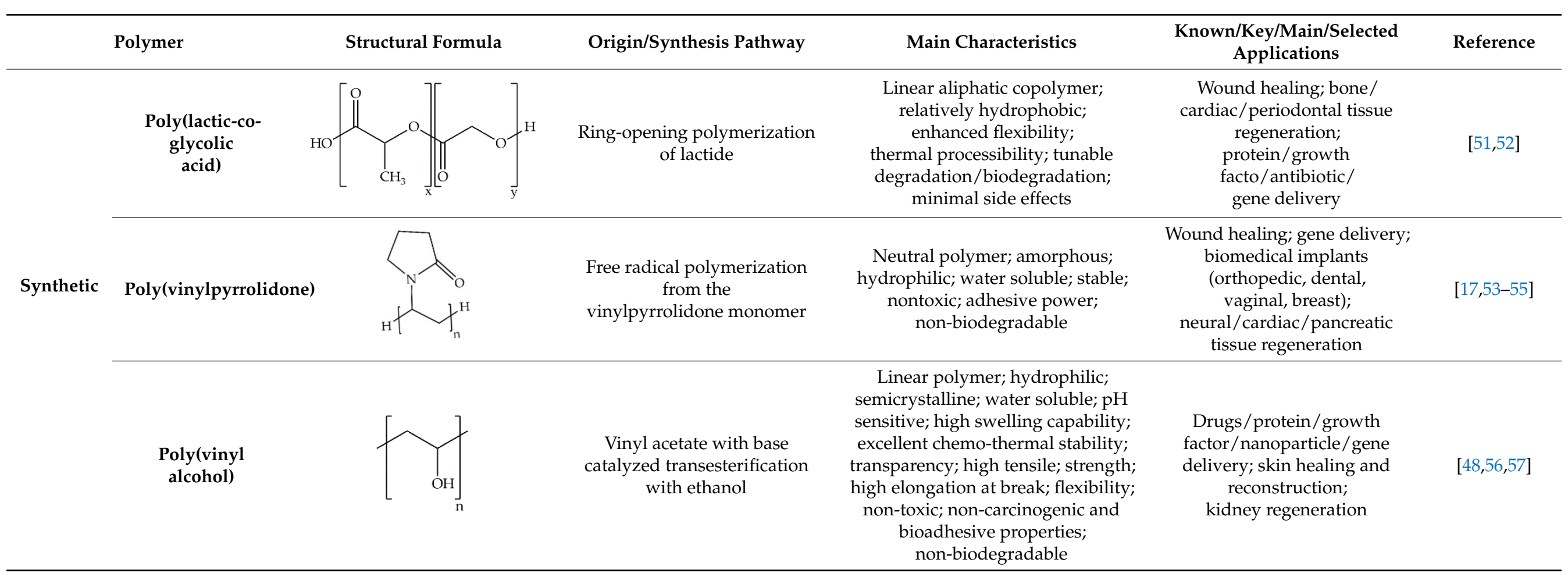




\section{Hydrogel}

Hydrogels are 3D networks of hydrophilic polymers capable of absorbing and retaining significant amounts of fluids [58], which have also been widely applied in wound healing [30,59]; cartilage tissue engineering [36,60]; bone tissue engineering [61]; and delivery of proteins, growth factors and antibiotics [20,62].

Hydrogels can be classified based on their source, namely the composing polymers, in natural or synthetic (Table 2). Thus, nature-derived hydrogels may consist of natural polysaccharides or polypeptides [6,12], ergo carrying molecular recognition sites enabling cell/tissue communication pathways and modulation towards a therapeutical effect [63]. However, as hydrogels, they tend to present low stability in aqueous medium, poor mechanical properties and quick degradation rates [63]. On the other hand, hydrogels based on synthetic polymers are typically mechanically resilient and display superior elastic properties. Still, their biological inertness, blocking any chances of tuning cell behavior towards a healthier state, limits their use in biomedicine $[63,64]$. Hybrid hydrogels, combining natural and synthetic polymers [65], have been proven useful to create smart hydrogels (alginate-g-(PEO-poly(propylene oxide)-PEO) [66]), in biomedical materials (PVA/collagen [67]) and in tissue engineering applications (CS/PCL [47]), to name a few examples. Their polymer composition may also subdivide hydrogels in homopolymers, copolymers, multipolymers or interpenetrating polymer networks (IPN) [68]. Homopolymer hydrogels are made of crosslinked polymer networks derived from a single type of basic structural unit (monomers) [69]. Copolymer hydrogels are frequently crosslinked polymer networks made up of two co-monomer units with at least one hydrophilic component (not soluble in water). These networks can assume three types of configuration, arbitrary, block or may alternate between both along the chain [70,71]. Multipolymer hydrogels are the result of the reaction of three or more co-monomers [72]. In turn, IPNs are an important class made of two independent crosslinked synthetic and/or natural polymer components, in which a new hydrogel polymeric network is polymerized within a pre-existent $[68,73]$. In case only one polymer network from the two is crosslinked, the hydrogels are designated as semi-IPNs. [68].

Table 2. General classification of hydrogels considering their source, polymers charge, polymer composition, structural configuration, degradation, physical properties, response to stimuli, and type of crosslinking [68].

\begin{tabular}{cc}
\hline & Hydrogels Classification \\
\hline Source & Natural, synthetic or hybrid \\
\hline Charge of polymers & Ionic, non-ionic, amphoteric or zwitterionic \\
\hline Polymeric composition & Homopolymer, copolymer, multipolymer, IPN or semi-IPN \\
\hline Configuration & Amorphous, crystalline or semicrystalline \\
\hline Degradability & Biodegradable or non-biodegradable \\
\hline Physical properties & Conventional or smart \\
\hline Response & Physical, chemical, or biochemical/biological \\
\hline Type of crosslinking & Chemical or physical \\
\hline
\end{tabular}

Hydrogels may also be categorized as amorphous, crystalline or semi-crystalline, depending on their physical organization and chemical composition. Semicrystalline hydrogel networks are mixtures of crystalline as well as amorphous phases [74]. These properties may also affect the hydrogel degradation rate, sub-divided in degradable or non-degradable structures [68]. Most hydrogels used in tissue engineering and drug delivery systems are biodegradable and are developed to degrade into biologically acceptable molecules (non-toxic degradation biproducts) [75,76]. The degradation rate of biodegradable hydrogels may be manipulated via the polymers' molecular weight [77], 
by the action of oxidizing agents [78], or by the presence of enzymes [79]. Tanan et al. developed a semi-interpenetrating hydrogel (semi-IPN) consisting of a mixture of cassava starch-g-polyacrylic acid/natural rubber/PVA. This hydrogel exhibited an excellent water retention capacity and proved to be highly sensitive to salt concentration, type of cations, $\mathrm{pH}$ and swelling time. In addition, it demonstrated good biodegradation with a rate of 0.626 wt.\%/day [80].

In terms of their physical properties, hydrogels can be categorized as conventional or smart. Conventional hydrogels are characterized by low response rates, in general. They have a very low swelling rate due to their small matrix size. This limitation has triggered a greater interest in macroscopic hydrogels, where the size of the pores allows a higher swelling rate. Smart hydrogels are hydrogels that react to changes in environmental conditions (external stimuli) by swelling or reversibly collapsing [81,82]. Hydrogels can be physical, chemical or biochemical/biological in relation to the type of response/stimulus [68]. Physical stimuli like temperature, electric field, magnetic field, light and pressure and chemical stimuli like $\mathrm{pH}$, solvent composition and ionic strength can change the swelling state of the hydrogel. Hydrogels with biochemical/biological responses are capable of interacting with the surrounding environment $[81,83]$. In terms of production, hydrogels can be formed by physical [30] and/or chemical [21] crosslinking of polymers, which will be discussed in the following sections. Hydrogels can also be classified based on their charge in non-ionic (neutral), ionic (anionic or cationic), amphoteric (acidic and basic groups) or zwitterionic (anionic and cationic groups in each structural unit) [68].

Hydrogels benefit from a high degree of flexibility, adjustable viscoelasticity, biocompatibility, high permeability to oxygen and essential nutrients, high water content and low interfacial tension with aqueous medium $[7,22]$. The hydrogel biocompatibility, that is, its ability to perform its intended function without inducing side effects in the host, is one of its most crucial characteristics. Further, in case of wounds, for instance, their limited adhesion may allow removal from the wound bed without causing additional trauma or destroying the newly formed tissues $[84,85]$.

Certain hydrogels even have capacity to alter their swelling state in response to environmental variations; these function as triggers to change the physical and/or chemical properties of the hydrogel. For example, in the case of $\mathrm{pH}$-sensitive hydrogels, the polymers that make up the hydrogel contain hydrophobic moieties that swell in water according to the $\mathrm{pH}$ of the external environment. Thus, in the absence of this stimulus, the hydrogel maintains its initial swelling state [81]. This property makes them good candidates for drug delivery systems. In this case, altering the swelling state in response to a change in $\mathrm{pH}$ opens opportunities for controlling the timing of drug release. Kwon et al. described the synthesis via chemical crosslinking of $\mathrm{pH}$-sensitive hydrogels based on hydroxyethyl cellulose and HA for transdermal delivery of the drug isoliquiritigenin. At $\mathrm{pH} 7$, the electrostatic repulsions between the carboxylate groups of HA lead to the enlargement of mesh and, consequently, to an increase in the amount of isoliquiritigenin released. The authors observed an efficacy greater than $70 \%$ of the release of the drug due to the $\mathrm{pH}$ and excellent adhesive properties of the hydrogel, which makes it a good candidate for treating skin lesions [86].

\section{Hydrogel Formation: Techniques}

Considering that many hydrogels degrade very easily in biological systems or in contact with water-based fluids, the purpose of the crosslinking process is to improve the insolubility, mechanical strength, and rigidity of the polymer network. Hydrogels can be physically or chemically crosslinked (Table 3) [87]. Physical hydrogels are networks with transient junctions (reversible connections), traditionally disordered and fragile. They result from interactions such as ionic bonding [88], hydrogen bonding [89], hydrophobic interactions [90], and crystallization [91]. The physical properties of the polymers and the gelation conditions determine the internal structure of the hydrogel, by modulating properties such as gel density, porosity and mechanical performance (e.g., rigidity) [92]. 
Physical hydrogels tend to exhibit low mechanical strength and are often unstable [93]. The dissolution of physically crosslinked hydrogels can occur in response to changes in temperature, application of stress, ionic strength, $\mathrm{pH}$ and solvent composition. Because of their reversible character, the polymer solution resulting from the dissolution process may undergo again gelation and restore the original hydrogel features [65,94].

Unlike physical, chemical hydrogels are polymer networks with permanent junctions, formed via covalent bonds, which are capable of maintaining the structure integrity for longer (increased degradation time) [95]. Chemically crosslinked hydrogels are known to be mechanically strong. However, although they present a permanently fixed shape, they have low fracture resistance and extensibility [93]. Further, certain chemical crosslinking agents are toxic and can cause adverse reactions; thus, they must be extracted from the gels before use [96]. Photopolymerization, enzymatic crosslinking, crosslinking molecules and polymer-polymer crosslinking are the four major chemical crosslinking methods that can be employed to form crosslinked hydrogels. 
Table 3. Properties and limitations of different types of physical and chemical crosslinking.

\begin{tabular}{|c|c|c|c|c|c|}
\hline Hydrogels & $\begin{array}{l}\text { Crosslinking } \\
\text { Engine }\end{array}$ & Concept & Advantages & Disadvantages & Reference \\
\hline \multirow{3}{*}{ Physical } & $\begin{array}{l}\text { Ionic/Electrostatic } \\
\text { Interaction }\end{array}$ & $\begin{array}{l}\text { Interaction between a polyanion and a } \\
\text { multivalent cation or a polycation, and vice } \\
\text { versa (interaction between opposite charges) }\end{array}$ & Simple method; self-healing ability & $\begin{array}{l}\text { Low stability in physiological } \\
\text { environments and limited } \\
\text { mechanical strength }\end{array}$ & {$[29,94,97,98]$} \\
\hline & $\begin{array}{l}\text { Hydrogen } \\
\text { Bonding }\end{array}$ & $\begin{array}{l}\text { Hydrogen bond between polymer chains } \\
\text { (electron-deficient hydrogen atom and a } \\
\text { high electronegativity functional group) }\end{array}$ & Absence of chemical crosslinkers & $\begin{array}{l}\text { High dilution and dispersion } \\
\text { rate over a few hours in vivo }\end{array}$ & {$[85,99]$} \\
\hline & Crystallization & $\begin{array}{l}\text { The principle of freezing polymers at low } \\
\text { temperatures, followed by thawing at room } \\
\text { temperature causes the formation of crystals } \\
\text { which leads to the formation of hydrogels }\end{array}$ & $\begin{array}{l}\text { Stability and mechanical properties } \\
\text { can be increased with increasing the } \\
\text { freezing time and freeze-thaw cycles; } \\
\text { simple method; not require } \\
\text { additional chemicals and high } \\
\text { temperature }\end{array}$ & $\begin{array}{l}\text { Freeze/thaw processes } \\
\text { applied for long periods of } \\
\text { time can alter the behavior of } \\
\text { the hydrogel }\end{array}$ & {$[96,102-104]$} \\
\hline \multirow{2}{*}{ Chemical } & Photo-crosslinked & $\begin{array}{c}\text { The crosslinking of monomers or oligomers } \\
\text { is initiated in the presence of an irradiation } \\
\text { of UV/visible light and a photoinitiator that, } \\
\text { when absorbing photons, is cleaved and } \\
\text { forms free radicals that trigger } \\
\text { polymerization }\end{array}$ & $\begin{array}{l}\text { No toxic crosslinking agents are } \\
\text { required; excellent spatial and } \\
\text { temporal selectivity; low processing } \\
\text { cost and energy requirements }\end{array}$ & $\begin{array}{l}\text { The photoinitiator can } \\
\text { produce free radicals with } \\
\text { effects on immunogenicity } \\
\text { and cytotoxicity responses }\end{array}$ & {$[105,106]$} \\
\hline & $\begin{array}{l}\text { Enzymatic } \\
\text { Reaction }\end{array}$ & $\begin{array}{l}\text { Certain enzymes (e.g., transglutaminases, } \\
\text { horseradish peroxidase and tyrosinase) help } \\
\text { to catalyze crosslinked reactions between } \\
\text { two or more polymers }\end{array}$ & $\begin{array}{l}\text { Mildness of the enzymatic reactions } \\
\text { at normal physiological conditions; } \\
\text { high efficiency; selectivity; } \\
\text { non-toxicity; good biocompatibility; } \\
\text { fast gelation process; tunable } \\
\text { mechanical properties }\end{array}$ & $\begin{array}{l}\text { Instability and poor } \\
\text { availability of some of the } \\
\text { enzymes }\end{array}$ & [107-109] \\
\hline
\end{tabular}


Table 3. Cont.

\begin{tabular}{|c|c|c|c|c|c|}
\hline Hydrogels & $\begin{array}{l}\text { Crosslinking } \\
\text { Engine }\end{array}$ & Concept & Advantages & Disadvantages & Reference \\
\hline \multirow{2}{*}{ Chemical } & $\begin{array}{l}\text { Crosslinking } \\
\text { Molecules }\end{array}$ & $\begin{array}{c}\text { Crosslinkers (e.g., glutaraldehyde, } \\
\text { carbodiimide agents, genipin and citric acid) } \\
\text { are small molecules with two or more } \\
\text { reactive functional groups responsible for } \\
\text { the formation of bridges between } \\
\text { polymers chains }\end{array}$ & Easiness and versatility method & $\begin{array}{l}\text { Possible cytotoxicity of the } \\
\text { crosslinking agent (e.g., } \\
\text { glutaraldehyde) }\end{array}$ & [110-112] \\
\hline & Polymer-Polymer & $\begin{array}{l}\text { Crosslinking reaction occurs between } \\
\text { pre-functionalized polymer chains with } \\
\text { reactive functional groups under favorable } \\
\text { conditions. Polymer-polymer bonds can be } \\
\text { formed by Schiff bases and by Michael } \\
\text { addition reactions }\end{array}$ & Not using crosslinking molecules & $\begin{array}{l}\text { Requires the modification of } \\
\text { the polymer chains before } \\
\text { their conjugation }\end{array}$ & {$[113,114]$} \\
\hline
\end{tabular}


Hybrid hydrogels result from the combination of physical and chemical crosslinking of polymers. These double crosslinked hydrogels combine the advantages of both strategies, namely, low surface tension, remarkable thermodynamic stability and elevated capacity of solubilization $[65,93]$.

Various chemical and physical hydrogels have been prepared from natural and/or synthetic polymers for a variety of biomedical purposes. Chitosan hydrogels formed with the crosslinking agent trisodium salt 6-phosphogluconic (6-PG-Na ${ }^{+}$) loaded with the drug piroxicam were developed by Martinez-Martinez et al. The interaction between ionic polymer cationic groups and anionic groups of the 6-PG-Na+ crosslinker led to the formation of ionic hydrogels. The authors observed that the hydrogel had potential as a drug vehicle for topical administration since at $\mathrm{pH}$ close to neutrality there was less degradation than at lower $\mathrm{pH}$, with a release of $90 \%$ of piroxicam during $7 \mathrm{~h}$ (release controlled by $\mathrm{pH}$ ). This hydrogel proved to be a good candidate as a wound dressing given its good adhesion properties, non-toxicity and ability to induce healing and regeneration [115]. In another study, Wang et al. developed a hydrogel based on gelatin methacrylamine/poly(ethylene glycol)diacrylate (GelMA/PEGDA) via photo-crosslinking (with photoinitiator I2959). The engineered hydrogel was shown to have stronger mechanical properties than pure GelMA hydrogels and a degradation rate that lasted 4 weeks. Here, osteoblasts were able to adhere and proliferate along the surface, showing great cell viability and biocompatibility. Such characteristics make this hydrogel a good candidate for guided bone regeneration [116]. Table 4 lists some of the most recent examples physical, chemical and hybrid hydrogels employed in biomedicine and their respective production techniques.

Table 4. Examples of hydrogel crosslinking systems employed in wound dressing, tissue engineering and drug delivery.

\begin{tabular}{|c|c|c|c|c|}
\hline Hydrogels & $\begin{array}{l}\text { Crosslinking } \\
\text { Engine }\end{array}$ & $\begin{array}{l}\text { Hydrogel } \\
\text { Composition }\end{array}$ & Applications & Reference \\
\hline \multirow{9}{*}{ Physical } & \multirow{4}{*}{ Ionic Interaction } & 6-PG-Na ${ }^{+}$-crosslinked CS & Drug delivery; wound dressing & [115] \\
\hline & & $\begin{array}{l}\mathrm{CaCl}_{2} \text {-crosslinked } \\
\text { alginate-pectin }\end{array}$ & Wound dressing & [30] \\
\hline & & Poloxamer-heparin/gellan gum & $\begin{array}{l}\text { Bone marrow stem } \\
\text { cells delivery }\end{array}$ & [117] \\
\hline & & $\mathrm{Al}_{3}{ }^{+}$-crosslinked cellulose & Drug delivery & [118] \\
\hline & \multirow[b]{2}{*}{ Hydrogen Bonding } & PVA/poly(acrylic acid) & $\begin{array}{l}\text { Surgical sutures and } \\
\text { load-bearing fields }\end{array}$ & [119] \\
\hline & & $\begin{array}{l}\text { 1,6-hexamethylenediamine } \\
\text { (HMDA)-crosslinked cytosine } \\
\text { and guanosine modified HA }\end{array}$ & $\begin{array}{l}\text { Injectable drug delivery; soft tissue } \\
\text { engineering; } \\
\text { regenerative medicine }\end{array}$ & [120] \\
\hline & \multirow{3}{*}{ Crystallization } & PVA/poly(ethylene glycol) & Wound dressing & [121] \\
\hline & & CS/PVA & $\begin{array}{l}\text { Anti-inflammatory drug loading } \\
\text { and release }\end{array}$ & [102] \\
\hline & & PVA/cellulose & 2-layered skin model & [122] \\
\hline \multirow{4}{*}{ Chemical } & \multirow{4}{*}{ Photo-crosslinked } & PEGDA & Tissue engineered heart valves & [123] \\
\hline & & GelMA & $\begin{array}{l}\text { Tissue engineering; drug delivery; } \\
\text { regenerative medicine }\end{array}$ & [124] \\
\hline & & GelMA/PEGDA & Bone regeneration & [116] \\
\hline & & GelMA/CS & Tissue engineering & {$[60]$} \\
\hline
\end{tabular}


Table 4. Cont.

\begin{tabular}{|c|c|c|c|c|}
\hline Hydrogels & $\begin{array}{l}\text { Crosslinking } \\
\text { Engine }\end{array}$ & $\begin{array}{l}\text { Hydrogel } \\
\text { Composition }\end{array}$ & Applications & Reference \\
\hline \multirow{7}{*}{ Chemical } & \multirow{3}{*}{ Enzymatic Reaction } & $\begin{array}{c}\text { Horseradish peroxidase } \\
\text {-crosslinked HA/silk fibroin }\end{array}$ & Tissue engineering & [21] \\
\hline & & $\begin{array}{l}\text { Horseradish peroxidase } \\
\text {-crosslinked Silk fibroin- } \\
\text { tyramine-substituted silk fibroin } \\
\text { or gelatin }\end{array}$ & Cell delivery & [125] \\
\hline & & $\begin{array}{c}\text { Transglutaminase-crosslinked } \\
\text { gelatin-laminin }\end{array}$ & $\begin{array}{l}\text { Neuromuscular tissue } \\
\text { engineering }\end{array}$ & [126] \\
\hline & \multirow{3}{*}{ Crosslinking Molecules } & Genipin-crosslinked CS & $\begin{array}{c}\text { Drug delivery systems in oral } \\
\text { administration } \\
\text { applications }\end{array}$ & [111] \\
\hline & & Genipin-crosslinked CS/gelatin & Drug delivery & [127] \\
\hline & & Glutaraldehyde-crosslinked CS & Tissue engineering & [128] \\
\hline & Polymer-Polymer & CS/Alginate & $\begin{array}{l}\text { Neuronal tissue } \\
\text { engineering }\end{array}$ & [129] \\
\hline Hybrid & $\begin{array}{c}\text { Chemical Crosslinking } \\
\text { followed by } \\
\text { Crystallization }\end{array}$ & $\begin{array}{c}\text { Ethylene glycol diglycidyl } \\
\text { ether-crosslinked } \\
\text { microcrystalline Cellulose/PVA }\end{array}$ & Drug delivery & [130] \\
\hline
\end{tabular}

\section{Fiber}

The use and production of polymer-based fibers by humans has been described since pre-historic times. The earliest account of the biomedical use of fibers is suggested in decorations of the Tassili caves, engraved between 5000-2500 BC [131]. Ancient records, date the beginning of the use of cotton to the first half of the 6th millennium $\mathrm{BC}$ and the cultivation of silkworms to produce silk fibers to the 4th millennium BC [132,133]. With the industrial revolution, there was a need to create more efficient fiber production strategies. In the 14th century, the spindle to manufacture wool and cotton fibers emerged. The evolution in this field did not stagnate and the production of fibers continue evolving until the 19th century, dramatically increasing the use of natural fibers in the 1940s [11,134]. Years later, in the middle of the 20th century, the production of synthetic fibers began [11]. Nowadays, this area is constantly evolving, being already available several high precision methods of fiber production $[133,135]$. The application of fibers in biomedicine occurs in several areas, namely in wound dressings [136], bone tissue engineering [137], drug-controlled release [138], among others.

Fibers can be divided in two classes, natural and synthetic. Natural fibers can be extracted from plants, animals or minerals. Synthetic or man-made fibers usually arise from chemical processing [135]. In general, all plant-derived fibers are composed of cellulose, while animal-derived fibers contain proteins [139]. Natural fibers are made of millions of macrofibrils, which in turn are formed by microfibrils [140], composed mainly of crystalline cellulose (30-90\%, that varies depending on the part of the plant concerned) surrounded by an amorphous matrix of lignin and hemicellulose [141]. These three fiber components are linked together by covalent bonds [140], with the fiber properties being defined by their composition, microfibril angle, crystallinity and internal structure. The stiffness of the fibers depends essentially on the angle of the cellulose microfibrils, the smaller the angle the greater the stiffness. Other properties, such as water absorption, moisture resistance, swelling and integration of the fiber bundle are determined by the other components, like hemicellulose [141]. In general, vegetable fibers are characterized by their biodegradable nature, lightweight, renewable capacity, abundance, improved mechanical properties, low cost and low density [142,143]. Because of these characteristics, natural fibers can be processed in various forms, including rope, yarn and reinforcing 
agents for biocomposites [144]. However, as reinforcements, the quality and efficiency of the final product are dependent on environment conditions which may be unpredictable from batch to batch, generating heterogeneity between fibers with the same origin [142]. Cellulose nanofibers have been applied in areas such as drug delivery [145] and tissue engineering [146]. Doench et al. reported the development of non-cellularized injectable suspensions of viscous CS solutions, filled with cellulose nanofibers as a strategy for viscosupplementation of the intervertebral disc nucleus pulposus tissue [146]. Natural fibers derived from animal sources can be collected from wool, silk and hair, for instance [139]. In the case of wool, depending on the animal it is collected from, be it sheep, lama or rabbit, there are properties that vary, namely, the color and the weight of the fibers [147]. Keratin is the main component of wool and hair [148]. This protein has excellent biocompatibility, biodegradability and is capable of increasing scaffolds elasticity and mechanical resilience by self-assembly and polymerization [149]. Silk fibers, on the other hand, are mainly made up of two structural proteins, fibroin (mechanical strength) and sericin (coating) that can be organized in a linear structure [150]. Silk fibers are characterized by being biodegradable and biocompatible. Although in the past their use was limited to clothing, today, silk is used in surgical knits, sutures, and wound healing. In addition, several researches are now in course to examine their use in films, scaffolds, electroplated materials and hydrogels $[133,151]$. In fact, the increase in research on polymeric composites reinforced with natural fibers has emerged side by side with the use of synthetic fibers in polymeric composites [143].

Synthetic fibers can be classified in inorganic or organic. Inorganic fibers are those that are not made of organic compounds [152]. As such, organic fibers can be manufactured either from natural or synthetic polymers. Most of the fibers used are of polymeric origin. Thus, the molecular weight of the polymer fiber plays a crucial role in influencing the tensile strength and the physical properties of the final construct [153]. Synthetic polymer fibers can be prepared from various polymers, as can be seen in Table 5 [153]. However, in biomedicine, those endowed with biodegradable features attract much more attention, namely, the PLA and the PCL polyesters [154]. PLA has the potential to replace fossil-based polymers [139]. It is biocompatible and its degradation biproducts are non-toxic, which favors its application in health-related fields [155]. On its turn, PCL is a biocompatible, linear polyester with improved elastic properties (despite having low tensile strength, it is capable of very high elongation) [154] that make it highly desirable for tissue engineering systems [156].

Table 5. Examples of natural and synthetic fibers $[135,153]$.

\begin{tabular}{ccc}
\hline & Type of Fibers \\
\hline \multirow{2}{*}{ Natural } & Plant & $\begin{array}{c}\text { Bast fibers (e.g., jute and flax); seed fibers (e.g., cotton and coir); leaf fibers (e.g., banana } \\
\text { and abaca); grass fibers (e.g., sugarcane bagasse and bamboo); straw fibers (e.g., rice, corn } \\
\text { and wheat); wood fibers (e.g., softwood and hardwood) }\end{array}$ \\
\cline { 2 - 3 } Synthetic & Animal-Based & Wool; silk; hair \\
\cline { 2 - 3 } & Inorganic & $\begin{array}{r}\text { Metals and alloys (e.g., metals fiber); metal or semi-metal compounds (e.g., glass and } \\
\text { ceramics fibers); carbon-based fibers (e.g., carbon and graphene fibers) }\end{array}$ \\
\hline & Organic & $\begin{array}{c}\text { Synthetic polymers (e.g., polyamide nylon, polyethylene terephthalate, } \\
\text { phenol-formaldehyde, PVA, polycarbonate, polyvinyl chloride and polyolefins } \\
\text { (polypropylene and polyethylene)); natural polymer (e.g., chitosan and alginate) }\end{array}$ \\
\hline
\end{tabular}

Numerous researches describe the combination of synthetic polymers and natural polymers as the key for a successful fiber production [157-159]. For instance, Hu et al., reported the production of alginate/PCL composite nanofibers by co-electrospinning to enrich cancer stem cells (CSCs) constructs. The author studied the impact of the separated PCL and alginate fibers and the alginate/PCL composite having observed that the application of composite fibers is more effective in selecting cells than pure fibers. The fact 
that these scaffolds can be adjusted (composition proportion) to isolate CSCs from different tissues may potentially facilitate cancer research [157]. Levengood et al. developed CS/PCL nanofiber structures that combined the biological properties of CS and the stability and mechanical integrity of PCL for prospective applications in skin tissue engineering. Throughout the study, it was found that the nanofiber structure increased the wound healing rate, promoted general closure, re-epithelialization, maturity of the neoepidermis and collagen deposition when compared to the control. Such facts strengthen the potential of CS/PCL nanofiber structures for skin repair [158]. The other section of synthetic fibers, the inorganic fibers, can be subdivided in three main groups, which are the metals and alloys, the metal or semi-metal compounds and the carbon-based fibers (Table 5).

Many of the inorganic fibers generally exhibit high strength, high thermal and chemical stability and stability against any kind of organic solvent [152]. Regarding fiber glass, they have a relatively low cost, high tensile strength, high chemical resistance and good insulation properties. In case of carbon fibers, these have numerous advantages, such as high stiffness and tensile strength, high chemical resistance, high temperature tolerance, present low cost and low thermal expansion. Because of these characteristics, both glass fibers and carbon fibers are often used as reinforcement in polymeric composites [143]. These fibers can be combined with other components. Naskar et al. described a composite of regenerated silk protein fibroin reinforced with functionalized carbon nanofibers, loaded with growth factors (BMP-2 and TGF- $\beta 1$ ) essential to bone regeneration. The matrices formed were porous, immune-compatible and bioactive when incubated in simulated body fluid. Here, it was seen that the reinforcement of the nanofibers influenced the mechanical property of the matrices, increasing the compression module up to $46.54 \mathrm{MPa}$ [160].

Fibers can be classified according to their internal structure (uniform fibers or coreshell) or orientation (aligned or arranged randomly). They can also be formed of continuous monofilament yarns or multifilament yarns. Both natural and synthetic fibers can be characterized physically (diameter, length, density and moisture gain) and mechanically (tensile strength, specific strength young's modulus, specific young's modulus and failure strain) [161]. Natural fibers have moderate mechanical properties, high thermal sensitivity, low density, acceptable modulus-weight ratio, low cost, can be extracted from unlimited sources, and display good recyclability and biodegradability. However, the high sensitivity to humidity, higher variability of physical and mechanical properties and low durability are some of the disadvantages of natural fibers. In turn, synthetic fibers have high mechanical properties, low sensitivity to moisture and low thermal sensitivity. Limited sources and moderate recyclability are some disadvantages of synthetic fibers. [162,163]. Even though their mechanical resilience is highly attractive, the energy necessary to produce synthetic fibers tends to be more than that required for natural [140].

\section{Fiber Production: Techniques}

As explained earlier, the fiber final properties depend on the polymer composition. However, they are also dependent on the processing conditions. The four most used fiber production methods include electrospinning, melt-spinning, wet-spinning and dryspinning (Table 6). The electrospinning is a technique that allows the generation of polymeric fibers with submicron or nanometric diameters while conventional techniques such as melt-spinning, wet-spinning and dry-spinning can produce polymer fibers with diameters up to the micrometer range. 


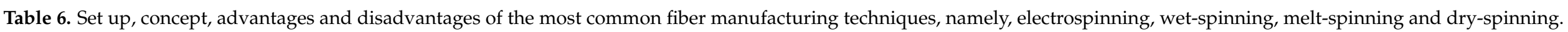

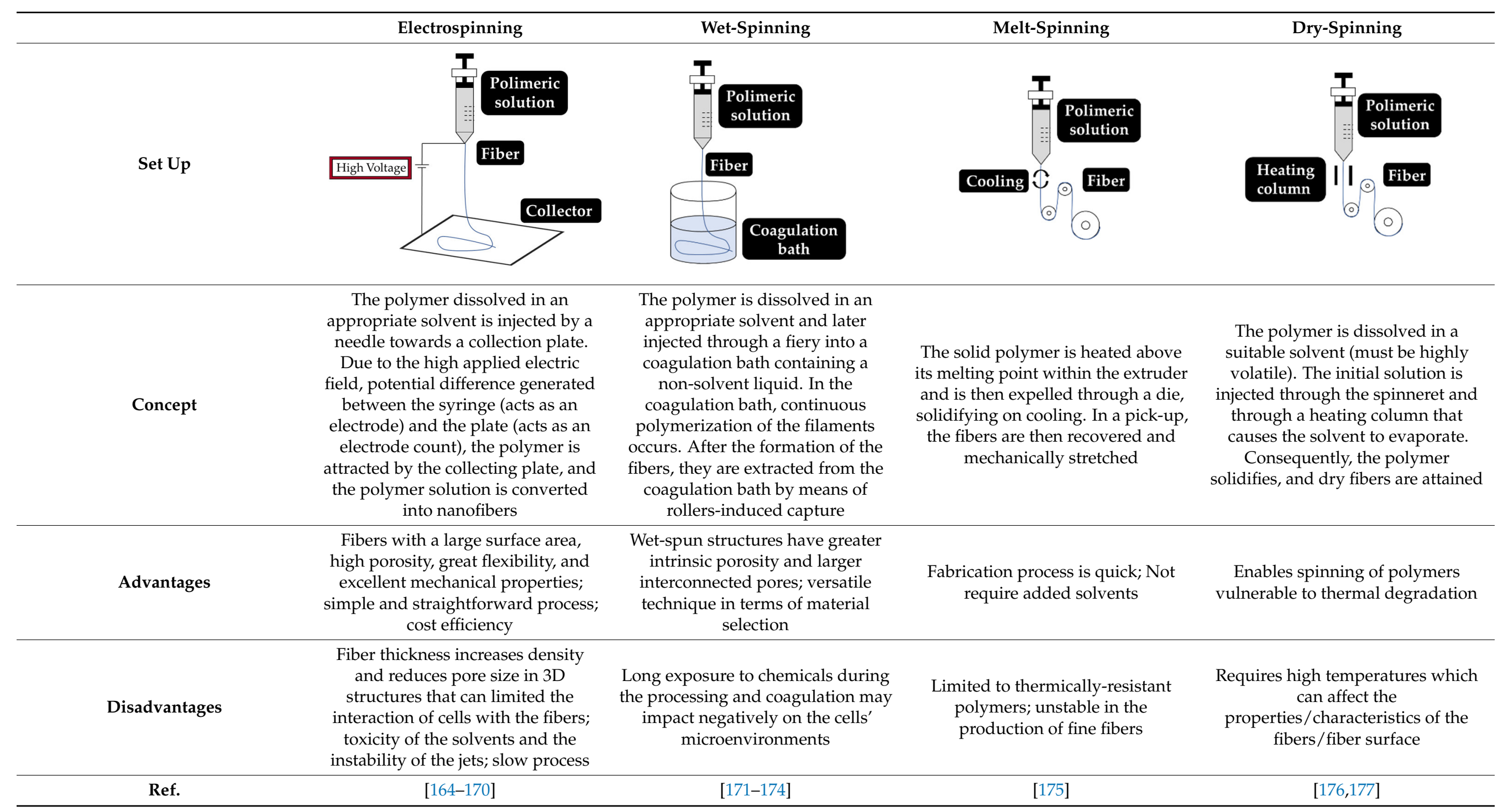


Depending on the fiber production method employed, several precautions must be taken into consideration, such is the case with the processing of CS fibers via wet-spinning. CS fibers have a very low tensile strength (due to their increased hydrophilicity) and, therefore, chemical crosslinking must be induced by Epichlorohydrin $(\mathrm{ECH})$ to improve its wet tenacity [178]. According to the chemical (e.g., composition and rate of degradation) and physical (e.g., diameter, strength and porosity) characteristics, the electrospun nanofibers can guide and interact with the injured tissue to improve wound healing [179].

\section{Fiber-Hydrogel Composites}

As seen in the previous sections, both hydrogels and fibers display great potential in biomedicine, particularly in the wound healing and drug delivery areas $[88,156,157,180]$. Despite the many advantages that make these scaffolding systems promising, there are still aspects that often limit their application. For instance, the low mechanical stability of natural hydrogels and the not-so-great biocompatibility of synthetic hydrogels tend to constrain their uses [63]. In the case of fibers, there is a limitation associated with the lack of 3D network formations which can restrict cell migration/infiltration [181]. Given these limitations, a number of researches are now dedicated in combining the advantages of fibers and hydrogels to produce an optimal, highly functional composite system [182-184]. In this sense, the objective of these investigations is to optimize the mechanical/biological functionalities of composites by promoting the combination of beneficial properties of both components (fiber/hydrogel) and reducing the impact of their undesirable features in the final application. The mechanical properties of hydrogels, in this case fiber-hydrogel composites, are significantly influenced by the addition of fibers [185], as they serve as a structural support for the hydrogel to surround, for instance [184]. Regev et al. reported that the incorporation of bovine serum albumin fibers in dextran/gelatin hydrogels increases the elasticity modulus of the hydrogel and decreases its gelation time [186]. Gelatin nanofibers aligned and infiltrated in alginate hydrogels may also increase the tensile modulus and rigidity of the overall hydrogel construct [187].

The fibers used in fiber-hydrogel composite can have different origins, natural or synthetic, and, at a morphological level, they can also differ depending on the desired application. Generally, the fibers used in these composites can be classified as long or short, and within the composite, they can exhibit a continuous or discontinuous pattern. Specifically, long and continuous fibers produced by electrospinning tend to possess small pores that limit cellular penetration and growth [188]. Based on the potential application of the scaffold, the organization of the fibers is a crucial element for the performance of the intended function, which can be oriented uniformly or randomly [185]. Although the available literature is still limited, several methods of combining fibers with hydrogels for the creation of composites with different structures have been reported. Of all, the most common arrangements of composite fiber-hydrogel structures are the stacked, with hydrogels and fibers forming layers (laminated composites) [189], the encapsulated, with fibers being enclosed within the hydrogel matrix [190], the injectable composites [191] and the electrospinning and electrospraying combination [192] (Figure 1). In fiber production, electrospinning is one the most used techniques due to its simplicity, cost efficiency, flexibility, scalability the advantage of mimicking the natural extracellular matrix (ECM) $[16,166,193,194]$, so its combination with hydrogel fabrication methodologies is very frequent. 


\section{Structural arrangements of fiber-hydrogel composites}
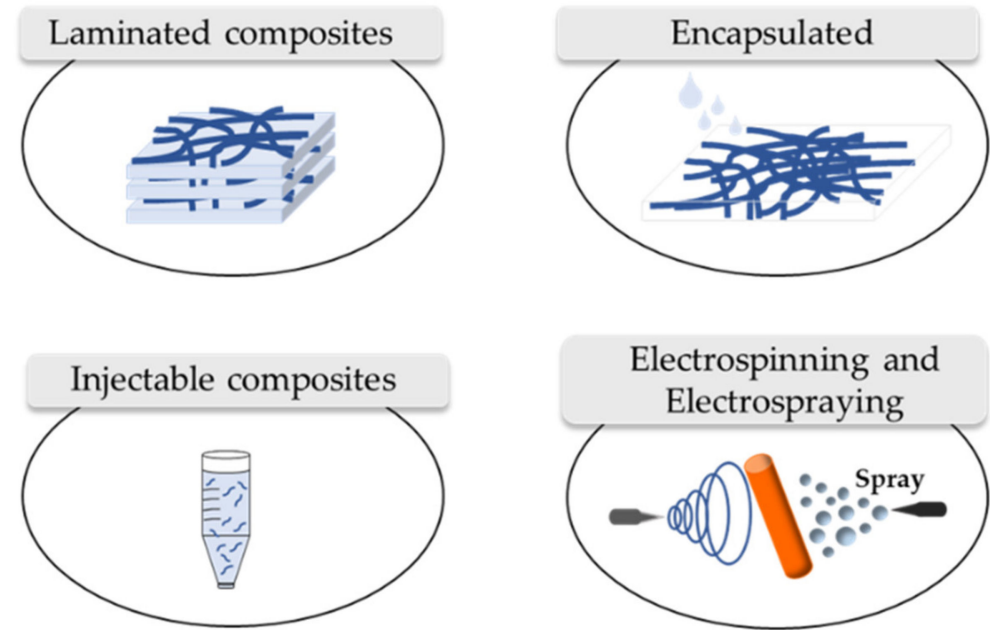

푼 Fibers

Hydrogel

Hydrogel solution

\section{Applications}
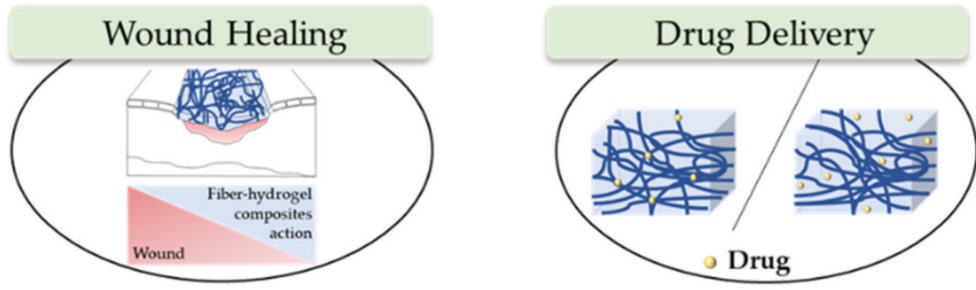

Figure 1. Structural arrangements of fiber-hydrogel composites and their applications in wound healing and drug delivery. Fiber-hydrogel composites with laminated structure result from the junction of individually manufactured fibers and hydrogels that can be organized in layers with different orientations. The encapsulation of fibers in hydrogels can result from crosslinking of the hydrogel solution directly into the fibers. In case of injectable composites, small individual fiber fragments are added to the hydrogel solution, resulting in an encapsulated and injectable composite structure. These composites can also be formed by the simultaneous combination of electrospinning and electrospraying applied directly towards a single collecting system (shown in orange).

Laminating is the simplest method to yield a fiber-hydrogel composite scaffold. Laminated composites consist of the junction of individually manufactured hydrogels and fibers in different layers. The number of fiber layers influences the mechanical properties of the composite. These composites can be formed by a single layer of fibers or by multilayers, with different orientations (e.g., $0^{\circ}, 45^{\circ}$ and $90^{\circ}$ ). The orientation of the fibers within the composite allows to control the toughness and strength of the final structure. These constructs exhibit significantly improved tensile properties compared to hydrogels alone [195]. However, they can undergo delamination very easily after water absorption due to the weak interactions between layers [196]. Additionally, the 2D structure of the fibers becomes a limitation for applications where it is essential to mimic the ECM, since this structure makes cell migration very challenging [197]. Encapsulating fibers in hydrogels can be accomplished by crosslinking the hydrogel directly into fibers with a pre-determined architecture or by immersing the fibers in a hydrogel precursor solution. In this process, the gaps between the fibers are occupied by the hydrogel precursor solution that later crosslinks. 
Based on encapsulation fibers in hydrogel, McMahon et al. hypothesized a composite with a tubular structure with circumferential mechanical properties similar to coronary artery vessels $[187,190]$. Papaparaskeva et al. projected prefabricated fibrous mats of PVP/silver nanocomposites incorporated within semi-IPN hydrogels in two unique forms of laminated dispersion (a prefabricated electrospun fibrous mat was placed in the circumference of the fiber/hydrogel composite) and homogeneous (a 2D circular fibrous mat was homogeneously encapsulated within a 3D hydrogel matrix). They noted that the dispersion mode of electrically spun fibrous mats within the hydrogel significantly influences the mechanical performance of the resulting composite [198]. Injectable composites have been considered an alternative to produce fiber-hydrogel constructs with homogeneous qualities. In this type of composite, small individual fiber fragments (smaller sizes facilitate injectability) are added to a hydrogel precursor solution. Subsequently, these fibers are incorporated into the crosslinked hydrogel matrix (in the desired environment), playing a reinforcing role. This production strategy is minimally invasive; however, the absence of connections between fibers can become a restriction for certain applications $[188,199]$. The electrospraying process has been used to form fiber-hydrogel composites. Here, the hydrogel solution is sprayed in fine droplets on fibers produced by electrospinning. These drops, which are deposited on the fibers, can have different sizes, from nanometers to several micrometers. The electrospinning-electrospraying has therefore low cost and is easy to operate. Furthermore, it allows to obtain a composite fiber-hydrogel with different structures and with adjustable size and morphology [200-202]. Despite the formation processes of fiber-hydrogel composites mentioned above, which are already used in investigations, a less positive aspect can be highlighted. This focuses on the differences in hydrophilicity between the fibers and the hydrogels that can cause some incompatibility, which then may result in a separation of the compound. In this sense, the modification of the fiber surface is considered a potential solution to improve this limitation [203-205].

There are several approaches that have been used to improve the properties of fibrous scaffolds and hydrogels, namely the development of fiber-hydrogels composites (Figure 1). As seen, these composites continue to conform to the same guidelines applied for the fabrication of the individual parts, with peculiarities related to their fabrication being, as expected, associated to polymer and solvent selection and combination of compatible processing methodologies. In general, the applications of scaffolds depend on their mechanical and biological properties and, as such, many possibilities have emerged in recent years.

\section{Applications of Fiber-Hydrogel Composites}

Recently, research on fiber-hydrogel composites has increased significantly. These scaffolding systems have been investigated for a range of applications, including wound healing [206], regeneration of corneal stroma [184], nucleus pulposus regeneration [201], bone tissue engineering [207], antibiotic delivery [208] and heart valve tissue engineering [209]. Scaffolds with an architecture that mimics native ECM and allows cell infiltration and differentiation has emerged as a prospective solution for the treatment of various health complications. For instance, the fibrous structure in fiber-hydrogel composites is considered of enormous importance for a greater efficiency of the scaffold. This is because tissues have biological fibers with specific composition and architecture that contribute to the normal function of the tissues. Thus, with this, it is possible to simulate biological fibers, approximating the foreign scaffold to living tissue and, thus, enhance cellular growth and maturation (e.g., cell differentiation) [184]. In the following sections, we will contextualize and list in more detail some recent examples of fiber-hydrogel composites applied in wound healing and drug delivery.

\subsection{Wound Healing}

Wound healing is a complex physiological response that involves a cascade of cells, matrix components and other biological factors [16]. In healthy people, wound healing includes four important phases: hemostasis, inflammation, proliferation, and remodel- 
ing. This complex process allows skin functions to be restored. Wounds that fail the normal healing process in a predictable amount of time are considered chronic wounds (CW) $[210,211]$. Currently, wound care is based on the application of a wide variety of wound dressings (gauzes, absorbent cotton and bandages), debridement, vacuum assisted closure and grafts. Even though they are considered the therapy of choice, wound dressing have some limitations, they are incapable of maintaining the moist environment necessary for wound healing and tend to adhere to the wound, which may cause discomfort to the patient when the dressing is removed [212]. CW treatments are often associated to high economic costs, an increase in surgical procedures and the greater susceptibility of the patient to infection. Microorganisms such as Acinetobacter baumannii, Enterococcus faecalis, Pseudomonas aeruginosa and Staphylococcus aureus have the ability to colonize and infect wounds, which complicate the healing process $[6,210]$. In the most severe cases, patients with infected wounds, such as diabetic foot infections, include mainly antibiotics in their therapy [213]. The impact of excess and inappropriate use of antibiotics has been explored in relation to the various adverse effects, such as bacterial resistance, which has been highlighted as a serious global concern [135]. Several alternatives have been developed for a more efficient wound healing in order to prevent infection to evolve and, in the case of CW, to try and shorten the treatment period [212,214-217]. There are some properties that ideally a modern wound dressing should have, specifically, the capacity for mechanical protection and adaptation to the shape of the wound, without adhering to wound tissue per se, so as not to cause pain to the patient when removed. Absorption capacity, cytocompatibility, flexibility, ability to ensure a balanced moist environment, induce wound healing, facilitate ECM regeneration, protect the wound from external contaminants and promote debridement are also important features in the development of an effective wound dressing $[6,33,166,212]$. Wound dressings can be classified based on the affinity of the dressing with the wound into four distinct groups: passive, interactive, advanced and smart dressings [211]. Modern dressings take the most varied forms, including hydrogels, films, sponges, foams, nanofiber mats and, more recently, fiber-hydrogel composites $[33,206]$. The hydrogel has the ability to absorb exudates and maintain a balance of moisture at the wounded site. In turn, the fiber mimics the fibrous structure of ECM. Since both structures present limitations, the fibers do not facilitate cell migration and hydrogels have low mechanical stability, scaffolds combining both have been the research target of many investigations in order to uncover alternatives for the treatment of wounds $[206,217,218]$. The combination of the two structure in one scaffold is expected to facilitate healing by generating an environment conducive with cell recognition and attachment (ECM mimicking) with a moist and breathable atmosphere required for a healthy tissue formation. It is known that a large part of mammalian ECM has an aqueous matrix (gel) containing diverse fibrous proteins, essentially collagen, elastin and fibronectin. These proteins surround and guide cells in vivo and act as an anchoring matrix $[219,220]$. In humans, fibrillar collagen provides tensile strength for ECM, which limits tissue/organ distensibility as is the case of the skin [221]. The ECM is mainly responsible for cell adhesion, migration, proliferation, and regulation of their action. For a complete and effective skin regeneration, it is important that a scaffold is created that mimics the structure and normal skin conditions. Studies have shown that the reinforcement of hydrogels with fibers improves cell function, differentiation and proliferation, as well as structural stability [182,183,195]. Indeed, Schulte et al. described the manufacture of an artificial ECM scaffold consisting of biofunctionalized fibers incorporated in a semi-synthetic hydrogel of HA that allowed the control of cell adhesion [220].

There are several polymers used in fiber-hydrogel composites, namely gelatin [206,217,222]. The combination of two separate scaffolds (bilayer scaffold) was studied by Franco et al. for a possible application in skin regeneration. The formulation consisted of a first layer based on a PCL/PLGA membrane (80:20) formed by electrospinning and a second layer of CS/gelatin hydrogel (50:50) crosslinked with glutaraldehyde. The first layer showed excellent mechanical properties and biocompatibility. In the case of the second layer, they 
obtained a porous structure, capable of swelling more than $500 \%$ of its dry size (excellent absorbent properties). The junction of the fibrous membranes provided better mechanical support to the scaffold and, at the same time, reduced the rate of degradation of the layer formed by the hydrogel [222]. In the same light, Zhao et al. through a chemical reaction of the methacrylamide groups with gelatin formed a prepolymer to produce fibers by electrospinning (GelMA). The electrospun GelMA nanofibers were crosslinked by photocrosslinking, with UV radiation. By manipulating the degree of modification of the gelatin with the methacrylamide groups and the photo-crosslinking time, it is possible to adjust the physical and biological properties. Characteristics such as water vapor permeability, water retention, mechanical resistance and kinetic degradation can be adapted by adjusting the time of UV light radiation. These GelMA scaffolds, which mimic the structure of the native ECM, demonstrated a better orientation of the cellular processes (e.g., cell migration of fibroblasts) and biocompatibility compared to the controls (gelatin and PLGA). The in vivo tests reinforce the potential of this scaffold since it was visible that they accelerated wound repair [217]. Sun et al. went a step further and reported the ability of the GelMA to improve the elastic biodegradable mechanical properties of the construct and its ability to improve cell adhesion, proliferation and vascularization [223]. In turn, Li et al. reports the use of gelatin for the development of a hydrogel fibers. Initially the gelatin-based compound hydrogel fibers were prepared by gel-spinning with PEG6000. Subsequently, the crosslinking agent dialdehyde carboxymethyl cellulose (DCMC) was incorporated in order to improve the thermal and mechanical properties of the hydrogel fibers composed of gelatin-PEG. This scaffold showed a strong capacity to absorb free water due to its 3D structure and porous network. The higher the DCMC content in hydrogel fibers, the more slowly they degrade. In addition, DCMC increased the compatibility of the hydrogel fibers with blood [206]. HA nanofibers are reported to promote wound healing. Due to their high solubility in water, crosslinking is required to increase their water stability. Chen et al. developed an electrospun a mixture of maleicated hyaluronate/poly(vinyl alcohol) methacrylate (MHA/MaPVA) that allowed the formation of mats with the capacity to swell and form fibrous hydrogels. The weight ratio of the nanofiber components influenced the morphology and diameter of the nanofibers. This structure was cytocompatible, promoted cell fixation and displayed high water absorption capacities [218]. PVA has also been combined with PCL to form double layer structures resultant from the combination of PCL nanofibers (hydrophobic) and PVA hydrogel (hydrophilic). After exposure to water, the PVA fiber layer was completely dissolved, and a hydrogel-like structure was formed. Despite this change, the defined shape of the scaffold was maintained due to the stability of the PCL layer in water-based environments. Several aspects were tested in this scaffold, namely, its morphology, wettability, and adhesion and proliferation of mouse fibroblasts. Here, it was seen that fibroblasts exhibited greater proliferative activity on the PCL side of the double layer. In the case of the PVA layer, the same was not seen, which may be a consequence of the greater hydrophilicity of the layer. Based on the behavior and characteristics of the double layer scaffold, the authors concluded that the scaffold had the potential to be used as a dressing or in the prevention of abdominal adhesions [194].

The rapid dissolution of fibers in an aqueous medium becomes a limitation for their application in active wound dressings. In the case of PVP fibers, their rapid solubility remains a problem despite their self-adhesive properties and their ability to incorporate molecules. Recently, to overcome this limitation Contardi et al. proposed to develop PVP-based fiber hydrogels containing hydroxycinnamic acid derivatives. A controlled release of p-cumaric and ferulic acids (derived from hydroxycinnamic acid) from the fibers was observed due to the incorporation of these in the hydrogel. The author also observed in burned skin a reduction in the levels of enzymes known to be positively regulated by reactive oxidative species in burned skin [224]. By electrospinning/electrospraying methods, Azarniya et al. reported the production of a hybrid fiber-hydrogel by combining fibrous mats and hydrogel particles. Through electrospinning, keratin/bacterial cellulose (BC) fibers were produced and simultaneously sprayed with thermosensitive hydrogel par- 
ticles. The chemically crosslinked hydrogel was composed of non-ionic triblock copolymers (PEO99-PPO65-PEO99; Pluronic F127) conjugated with Tragacanto gum (TG). Due to the low spinning power of keratin, poly(oxide of ethylene) (PEO) was added to the formulation forming the keratin/BC/PEO fibers. Reductions in the diameter of keratin/PEO fibers from $243 \pm 57 \mathrm{~nm}$ to $150 \pm 43 \mathrm{~nm}$ and hydrophobicity were observed with the addition of $1 \%$ or more of BC. However, despite the reduction of pores, TG and BC modified mats promoted cell fixation and proliferation in fibrous structures. It was seen that the hydrogel particles were uniformly incorporated into the junction of the fibrous network. This modification improved several features of the scaffolds, including hydrophilicity, modulus of elasticity $(31 \%)$, tensile strength (35\%) and ductility (23\%) [225]. More recently, Loo et al. developed "intelligent" peptide hydrogels, in which the short aliphatic peptides had the tendency to self-assemble into helical fibers, forming nanofiber hydrogels. These nanofibrous hydrogels were found to possess regenerative properties and to display potential to accelerate the healing of burn wounds [226].

\subsection{Drug Delivery}

In conventional therapies, rapid degradation and excretion of drugs during the circulation process in the body is frequently detected. Consequently, only a small amount of medication will have therapeutic effects in places of interest [227]. Several research groups have focused on the development of new controlled drug delivery systems to allow an effective distribution of drugs in the intended locations at a controlled release rate $[193,228]$. A drug delivery system is used to transport therapeutic substances in the body more effectively and safely, having the ability to control the amount, the time and the targeted place for drug release [229]. Several scaffolds have been used to encapsulate and deliver therapeutic drugs, namely, fibers and hydrogels [102,230-232].

Electrospinning systems allow drugs to be incorporated into the fibers, giving them a high drug loading capacity, increased initial burst, sustained release, and prolonged circulation. Methods of incorporation include blend (or $\mathrm{co}^{-}$, the drug is mixed in the polymer solution), side-by-side (vehicle/polymer solution and the biomolecules are loaded in a separate spinneret), multi-jet (use of multiple nozzles with one or more jets, or a nozzle with different jets), co-axial (two concentric aligned capillaries connected to a high voltage source) and emulsion electrospinning (the drug is encapsulated in an appropriate solvent to be protected from the fiber/solvent system) [48]. Just as there are different ways to incorporate drugs into fibers, drugs may also be released via three distinct mechanisms: desorption of the fiber surface, diffusion in the solid state through the fibers, and fiber degradation [233]. The fiber morphology and its high therapeutic load capacity are beneficial properties that make them potential candidates for drug delivery systems. Electrospun fibers have several advantages especially due to their large surface area and their absorption/release properties [234]. However, large-burst drug release, uncontrolled duration of drug release, and incomplete drug release are recurring problems. The possible agglomeration of bioactive agents on the surface of the fibers becomes a disadvantage of the electrospinning method since it can trigger an initial burst release, which may cause toxicity of the release site $[48,224,235]$. Such limitations may have implications in the scaffold biomedical goals.

To incorporate drugs into hydrogels, they can be loaded into the precursor solutions before crosslinking or can be absorbed after gelation [236]. Regarding drug release, swelling is an important property in some stimulus-sensitive drug delivery system. Certain changes in the environment may trigger swelling that allows the release of the drug due to the alterations in mesh size of the polymeric network [237]. Features like hydrophilicity, biocompatibility and tunable mechanical properties are the reason why hydrogels have been used extensively for the controlled release of drugs [193]. Although hydrogels are widely used in controlled release systems, there are some limitations that must be overcome. These scaffolds suffer from low mechanical resistance, which may be responsible for inhomogeneous release [236]. In most hydrogels, their ability to absorb large amounts of water 
and the presence of large pore sizes may trigger a rapid drug release [208]. In accordance, some investigations have developed/obtained better kinetic release profiles when there is a combination of hydrogels with other structures, namely fibers [193]. The effectiveness of fiber-hydrogel composites for drug administration has been demonstrated [208,227,228]. Nanofiber-hydrogel scaffolds as biofunctionalized platforms appear as attractive alternatives to the ineffective treatments related to direct drug administration.

Persistent neurological dysfunctions are usually triggered by spinal cord injuries due to failure in axon regeneration. Nguyen et al. synthesized lined mats of poly $(\varepsilon$-caprolactoneco-ethyl ethylene phosphate) (PCLEEP) by electrospinning and distributed them in a collagen hydrogel matrix. Both the fibers and the hydrogel contained neurotrophin-3 (model protein) known for promoting neuronal survival, axonal sprouting and regeneration. Additionally, the hydrogel contained miR-222 (model microRNA) known to contribute to the control of local protein synthesis at distal axons. Overtime, it was seen that degradation occurred within the collagen hydrogel, but the PCLEEP fibers maintained their morphology and alignment after 3 months. The composite framework allowed localized and sustained drug/gene delivery, while aligned nanofibers acted to direct remyelination of the injured area. Furthermore, they observed the regeneration of the animal model axon [227]. In a similar study, small fragmented nanofibers of poly(3-caprolactone- ${ }^{-}{ }^{-} \mathrm{D}, \mathrm{L}$-lactide) (PCL:DLLA) and collagen were individually dispersed in a hyaluronane-methylcellulose hydrogel (HAMC). These fiber-hydrogel composites were used as a cell-transport system multipotent neural/progenitor stem cells (NSPCs) for the treatment of spinal cord injuries. The results showed that the incorporation of fibers in the HAMC hydrogel influenced the behavior of the NSPC cells, highlighting a better neuronal and oligodendrocytic differentiation in the scaffold PCL:DLLA/HAMC compared to collagen/HAMC [199]. In both studies, the complex generated from the combination of fibers and hydrogels allowed for a faster cell development and consequent regeneration.

A laminated fiber-hydrogel composite based on PCL electrospun fiber mats coupled with poly(ethylene glycol)-poly( $\varepsilon$-caprolactone) diacrylate (PEGPCL) hydrogels processed by UV polymerization was developed to control the release of a model hydrophilic protein (e.g., bovine albumin serum, BSA). To study the release of the hydrophilic protein, BSA was added to the system before crosslinking. The results reported by Han et al. suggested the relevant role of PLC fibers (diameter of approximately $0.45 \mu \mathrm{m}$ ) in the release of the drug in a uniform and delayed manner, by reducing swelling of hydrogels and water penetration rates and by increasing the length of the diffusion path and the diffusivity of the drug. In addition, the bioactivity of proteins after release was proven since extension of PC12 cell neuritis was detected. In general, the PCL fibers in the PEGPCL hydrogel demonstrated an important role in three main areas: control of the release kinetics of the hydrophilic protein, reduction of burst release (initial) and increased duration of drug release (more than two months) [193].

Osteomyelitis is a bone disease caused mainly by methicillin-resistant Staphylococcus aureus (MRSA). Various antibiotics are administered to reduce this infection, namely the glycopeptide vancomycin hydrochloride (vanco- $\mathrm{HCl}$ ). The bacterial plaque that forms around the infected area limits treatment by preventing the diffusion of the antibiotic vanco-HCL to the infected site, which then requires the administration of high doses. This overuse of antibiotics in addition to their impropriate function can lead to systemic toxicity. To try and solve this problem, Ahadi et al. developed a scaffold made of poly(Llactide) (PLLA) fibers produced by electrospinning followed by aminolysed, encased in a hydrogel of silk fibroin/oxidized pectin. PLLA fibers were loaded with vanco- $\mathrm{HCl}$ to promote a more sustainable release of the antibiotic at the affected site, resulting in a $61 \%$ reduction in drug release. This scaffold revealed better mechanical properties compared to the single hydrogel (without fibers), namely, a higher crosslinking density (52\%), a higher compression module (30\%) and a lower expansion rate (15\%). Biologically, the fiber-hydrogel composite was seen to have activity against MRSA and to be cytocompatible with cells, largely due to the presence of fibers aminolized with drugs [208]. Ekaputra 
et al. developed by electrospinning/electrospraying a hybrid mesh of PCL/collagen and HA hydrogel, Heprasil ${ }^{\mathrm{TM}}$, loaded with vascular endothelial growth factors (VEGF) and platelet-derived growth factors (PDGF). It was seen that the fiber-hydrogel composite $\mathrm{PCL} /$ collagen-Heprasil was successful in allowing a double simultaneous loading of the growth factors VEGF165 and PDGF-BB and to promote their controlled release over a period of five weeks, in vitro [192]. Recently, biocompatible vehicles for the release of the crystal violet drug $(\mathrm{CV})$ have also been described, in which polydopamine microfibers (PDA) were incorporated in a pullulan (PHG) hydrogel crosslinked by poly(ethylene glycol) diglicidyl ether (chemical crosslinker). PDA fibers attributed the $\mathrm{pH}$-responsive drug release behavior to the PHG hydrogel. This happens in response to the acidic conditions, which increase the electrostatic repulsion force between the PDA (protonated and positively charged) and the drug CV (positive charge). This repulsion promotes the release of the drug, with a detectable a cumulative release of $60.3 \%$ (pH 7.4), which increased to $87 \%$ with a decrease in $\mathrm{pH}$ to 5. In addition, the incorporation of PDA fibers and the adjustment of their content allowed to regulate several properties of the composite PHG-PDAs, namely, its viscoelastic characteristics, mechanical performance, mesh size and swelling/disintegration properties of the PHG hydrogel. The developed scaffold proved to have great potential to be used in drug delivery systems, given its good cytocompatibility, non-toxicity and easily adjustable properties for a controlled release of CV [238]. Overall, data demonstrated the ability of the engineered systems to promote a controlled drug delivery, in which the fibrous mesh guaranteed the mechanical stability of the construct while the hydrogel released the loaded active compounds.

A new physical approach based on hydrogel and nanofibers (or NEEDs) for cell encapsulation has been described in the work of An et al. Here, tubular constructs with different compartments were developed, consisting of Nylon 6,6 nanofibers, manufactured by electrospinning, being subsequently impregnated in different hydrogel precursor solutions (alginate, chitosan or collagen) and crosslinked. Fibers had an average diameter of $200 \mathrm{~nm}$ with $1 \mu \mathrm{m}$ interconnected pores. Compartmentation proved to be an asset for co-encapsulation, co-culture and co-distribution of different individual cells and cellular aggregates (islets), with cell viability being observed. Finally, the potential application of NEEDs for cell therapies using a type 1 diabetic model was tested, and the disease was corrected (in 8 weeks), which proved the therapeutic potential of NEEDs within primary rat islets (without the disease) [228].

In wound healing, it is important to pay attention to the biomaterials used to produce wound dressing. To achieve the desired objectives, the properties of each biomaterial are optimally combined. Studies have shown that local administration of therapeutic agents through wound dressings can improve the wound healing process [16]. In fact, a bioactive dressing of fibers of silk fibroin (SF) produced via electrospinning was developed and then combined with the alginate hydrogel (ALG) capable of supplying amniotic fluid (AF). This dressing had the ability to release AF, highly enriched with various therapeutic agents, at the wound site. The AF release profile was related to the concentration of ALG (greater release of AF in lower amounts of ALG). The increase in cell proliferation and collagen dissemination and secretion due to AF in fibroblast cultures strengthens the potential of the SF/ALG fiber-hydrogel composite to accelerate the healing process in severe wounds [239]. In a similar study, a bi-layer dressing of gelatin nanofiber mats loaded with epigallocatechin gallate (EGCG)/PVA hydrogel was produced for the treatment of acute wounds. The hydrogel was used as a protective and hydrating outer layer of the bi-layer dressing. Jaiswal el al. observed that the decrease in crosslinking time led to a slower EGCG release profile. This increased in the 2-4 days release period demonstrating the ability of this scaffold to guarantee a gradual drug release. Faster wound contraction, improvement in angiogenesis, reepithelization and less inflammatory response compared to control were also observed [240]. More recently, Chen et al. developed CS/gelatin hydrogels with polydopamine-intercalated silicate nanoflakes (PDA-Silicate). These were electrospun in the form of nanofibers loaded with the antibiotic tetracycline hydrochloride 
(TH). In this sandwich-like nanofiber/hydrogel composite (NF-HG) the incorporation of the fibers in the hydrogel resulted in a restriction in the release of antibiotic TH. However, it allowed a sustained release rate of TH in NF-HG for long-term protection. In addition, this structure reduced the toxicity of the drug associated to the rapid release. Furthermore, the excellent adhesiveness and anti-infectious properties demonstrated by the NF-HG, turned this formulation particularly attractive to be used as a wound dressing [241].

\section{Conclusions}

The world of biomaterials, specifically polymers, continues to significantly impact on the field of biomedicine. The diversity of polymers and the different ways of using them in scaffolds have evolved considerably in the last years, proposing active solutions for daily problems. In recent decades, combinations of different scaffolding systems in one solution have been researched, demonstrating great potential in wound healing and drug delivery systems, particularly in the fight against antibiotic-resistant pathogens. Indeed, hydrogel and fiber composites have been engineered as effective therapies, overcoming many of the mechanical, physical, and biological limitations of fibers and hydrogels when used in individual systems. Although research in this field is still very limited and is basically taking the first steps, the potential is clear. In the next years, it is expected the research on these composites to continue evolving and growing, as the need for more adaptable and specialized biomedical devices grows as well.

Author Contributions: Conceptualization, M.O.T., J.C.A. and H.P.F.; writing original draft, M.O.T.; supervision, J.C.A. and H.P.F.; funding acquisition, H.P.F. All authors have read and agreed to the published version of the manuscript.

Funding: This research received funding from the Portuguese Foundation for Science and Technology (FCT) under the scope of the projects PTDC/CTM-TEX/28074/2017 (POCI-01-0145-FEDER-028074) and UID/CTM/00264/2021.

Institutional Review Board Statement: Not applicable.

Informed Consent Statement: Not applicable.

Data Availability Statement: Not available.

Acknowledgments: Authors acknowledge the Portuguese Foundation for Science and Technology (FCT), FEDER funds by means of Portugal 2020 Competitive Factors Operational Program (POCI), and the Portuguese Government (OE) for funding the project PEPTEX with reference PTDC/CTM-TEX/28074/2017 (POCI-01-0145-FEDER-028074). The authors also acknowledge project UID/CTM/00264/2021 of the Centre for Textile Science and Technology (2C2T), funded by national funds through FCT/MCTES.

Conflicts of Interest: The authors declare no conflict of interest.

\section{References}

1. Ratner, B.D.; Hoffman, A.S.; Schoen, F.J.; Lemons, J.E.; Wagner, W.R.; Sakiyama-Elbert, S.E.; Zhang, G.; Yaszemski, M.J. Introduction to Biomaterials Science: An Evolving, Multidisciplinary Endeavor. In Biomaterials Science: An Introduction to Materials in Medicine; Wagner, W., Sakiyama-Elbert, S., Zhang, G., Yaszemski, M., Eds.; Academic Press: Cambridge, MA, USA, 2020; pp. 3-19.

2. Mariani, E.; Lisignoli, G.; Borzì, R.M.; Pulsatelli, L. Biomaterials: Foreign Bodies or Tuners for the Immune Response? Int. J. Mol. Sci. 2019, 20, 636. [CrossRef]

3. Asim, M.; Jawaid, M.; Saba, N.; Ramengmawii; Nasir, M.; Sultan, M.T.H. Processing of hybrid polymer composites-a review. In Hybrid Polymer Composite Materials; Thakur, V.K., Thakur, M.K., Gupta, R.K., Eds.; Elsevier: Amsterdam, The Netherlands, 2017; pp. 1-22.

4. Ivanova, E.P.; Bazaka, K.; Crawford, R.J. Advanced synthetic polymer biomaterials derived from organic sources. In New Functional Biomaterials for Medicine and Healthcare; Ivanova, E.P., Bazaka, K., Crawford, R.J., Eds.; Woodhead Publishing: Cambridge, UK, 2014; pp. 71-99.

5. Asghari, F.; Samiei, M.; Adibkia, K.; Akbarzadeh, A.; Davaran, S. Biodegradable and biocompatible polymers for tissue engineering application: A review. Artif. Cells Nanomed. Biotechnol. 2016, 45, 185-192. [CrossRef] 
6. Ribeiro, D.M.L.; Júnior, A.R.C.; de Macedo, G.H.R.V.; Chagas, V.L.; Silva, L.D.S.; da Silva Cutrim, B.; Santos, D.M.; Soares, B.L.L.; Zagmignan, A.; de Càssia Mendonça de Miranda , R.; et al. Polysaccharide-Based Formulations for Healing of Skin-Related Wound Infections: Lessons from Animal Models and Clinical Trials. Biomolecules 2020, 10, 1-16.

7. Singh, M.R.; Patel, S.; Singh, D. Natural polymer-based hydrogels as scaffolds for tissue engineering. In Nanobiomaterials in Soft Tissue Engineering; Grumezescu, A.M., Ed.; William Andrew Publishing: Norwich, NY, USA, 2016; pp. 231-260.

8. Liu, Z.; Jiao, Y.; Wang, Y.; Zhou, C.; Zhang, Z. Polysaccharides-based nanoparticles as drug delivery systems. Adv. Drug Deliv. Rev. 2008, 60, 1650-1662. [CrossRef]

9. Mele, E. Electrospinning of natural polymers for advanced wound care: Towards responsive and adaptive dressings. J. Mater. Chem. B 2016, 4, 4801-4812. [CrossRef] [PubMed]

10. Bealer, E.J.; Onissema-Karimu, S.; Rivera-Galletti, A.; Francis, M.; Wilkowski, J.; la Cruz, D.S.; Hu, X. Protein-Polysaccharide Composite Materials: Fabrication and Applications. Polymer 2020, 12, 464. [CrossRef] [PubMed]

11. Miranda, C.S.; Ribeiro, A.R.M.; Homem, N.C.; Felgueiras, H.P. Spun Biotextiles in Tissue Engineering and Biomolecules Delivery Systems. Antibiotics 2020, 9, 174. [CrossRef] [PubMed]

12. Vandghanooni, S.; Eskandani, M. Natural polypeptides-based electrically conductive biomaterials for tissue engineering. Int. J. Biol. Macromol. 2020, 147, 706-733. [CrossRef] [PubMed]

13. Poole-Warren, L.A.; Patton, A.J. Introduction to biomedical polymers and biocompatibility. In Biosynthetic Polymers for Medical Applications; Poole-Warren, L., Martens, P., Green, R., Eds.; Woodhead Publishing: Cambridge, UK, 2016; pp. 3-31.

14. Nair, L.S.; Laurencin, C.T. Biodegradable polymers as biomaterials. Prog. Polym. Sci. 2007, 32, 762-798. [CrossRef]

15. Manavitehrani, I.; Fathi, A.; Badr, H.; Daly, S.; Shirazi, A.N.; Dehghani, F. Biomedical applications of biodegradable polyesters. Polymers 2016, 8, 20. [CrossRef] [PubMed]

16. Negut, I.; Dorcioman, G.; Grumezescu, V. Scaffolds for Wound Healing Applications. Polymers 2020, 12, 2010. [CrossRef]

17. Mondal, D.; Mollick, M.M.R.; Bhowmick, B.; Maity, D.; Bain, M.K.; Rana, D.; Mukhopadhyay, A.; Dana, K.; Chattopadhyay, D. Effect of poly(vinyl pyrrolidone) on the morphology and physical properties of poly(vinyl alcohol)/sodium montmorillonite nanocomposite films. Prog. Nat. Sci. Mater. Int. 2013, 23, 579-587. [CrossRef]

18. Salehi-Nik, N.; Rezai Rad, M.; Nazeman, P.; Khojasteh, A. Polymers for oral and dental tissue engineering. In Biomaterials for Oral and Dental Tissue Engineering; Tayebi, L., Moharamzadeh, K., Eds.; Woodhead Publishing: Cambridge, UK, 2017 ; pp. 25-46.

19. Duskey, J.T.; Baraldi, C.; Gamberini, M.C.; Ottonelli, I.; Da Ros, F.; Tosi, G.; Forni, F.; Vandelli, M.A.; Ruozi, B. Investigating Novel Syntheses of a Series of Unique Hybrid PLGA-Chitosan Polymers for Potential Therapeutic Delivery Applications. Polymers 2020, 12, 823. [CrossRef]

20. Liu, H.; Wang, C.; Li, C.; Qin, Y.; Wang, Z.; Yang, F.; Li, Z.; Wang, J. A functional chitosan-based hydrogel as a wound dressing and drug delivery system in the treatment of wound healing. RSC Adv. 2018, 8, 7533-7549. [CrossRef]

21. Raia, N.R.; Partlow, B.P.; McGill, M.; Kimmerling, E.P.; Ghezzi, C.E.; Kaplan, D.L. Enzymatically crosslinked silk-hyaluronic acid hydrogels. Biomaterials 2017, 131, 58-67. [CrossRef] [PubMed]

22. Tran, H.D.N.; Park, K.D.; Ching, Y.C.; Huynh, C.; Nguyen, D.H. A Comprehensive Review on Polymeric Hydrogel and Its Composite: Matrices of Choice for Bone and Cartilage Tissue Engineering. J. Ind. Eng. Chem. 2020, 89, 58-82. [CrossRef]

23. Felgueiras, H.P.P.; Wang, L.-M.; Ren, K.-F.; Querido, M.M.; Jin, Q.; Barbosa, M.; Ji, J.; Martins, M.C.L. Octadecyl chains immobilized onto hyaluronic acid coatings by thiolene "click chemistry" increase the surface antimicrobial properties and prevent platelet adhesion and activation to polyurethane. ACS Appl. Mater. Interfaces 2017, 9, 7979-7989. [CrossRef]

24. Shi, W.; Hass, B.; Kuss, M.A.; Zhang, H.; Ryu, S.; Zhang, D.; Li, T.; Li, Y.; Duan, B. Fabrication of versatile dynamic hyaluronic acid-based hydrogels. Carbohydr. Polym. 2020, 233, 115803. [CrossRef]

25. Dave, P.N.; Gor, A. Natural Polysaccharide-Based Hydrogels and Nanomaterials: Recent Trends and Their Applications. In Handbook of Nanomaterials for Industrial Applications; Hussain, C.M., Ed.; Elsevier: Amsterdam, The Netherlands, 2018 ; pp. 36-66.

26. Ranganathan, S.; Balagangadharan, K.; Selvamurugan, N. Chitosan and gelatin-based electrospun fibers for bone tissue engineering. Int. J. Biol. Macromol. 2019, 133, 354-364. [CrossRef]

27. Antunes, J.C.; Conçalves, R.M.; Barbosa, M.A. Chitosan/Poly( $\gamma$-glutamic acid) Polyelectrolyte Complexes: From Self-Assembly to Application in Biomolecules Delivery and Regenerative Medicine. Res. Rev. J. Mater. Sci. 2016, 4, 12-36. [CrossRef]

28. Goh, C.H.; Heng, P.W.S.; Chan, L.W. Alginates as a useful natural polymer for microencapsulation and therapeutic applications. Carbohydr. Polym. 2012, 88, 1-12. [CrossRef]

29. Lee, K.Y.; Mooney, D.J. Alginate: Properties and biomedical and applications. Prog. Polym. Sci. 2012, 37, 106-126. [CrossRef] [PubMed]

30. Rezvanain, M.; Ahmad, N.; Amin, M.C.I.M.; Ng, S.-F. Optimization, characterization, and in vitro assessment of alginate-pectin ionic cross-linked hydrogel film for wound dressing applications. Int. J. Biol. Macromol. 2017, 97, 131-140. [CrossRef] [PubMed]

31. Yan, G.; Chen, B.; Zeng, X.; Sun, Y.; Tang, X.; Lin, L. Recent advances on sustainable cellulosic materials for pharmaceutical carrier applications. Carbohydr. Polym. 2020, 244, 116492. [CrossRef]

32. Wang, J.; Tavakoli, J.; Tang, Y. Bacterial cellulose production, properties and applications with different culture methods-A review. Carbohydr. Polym. 2019, 219, 63-76. [CrossRef]

33. Teixeira, M.A.; Paiva, M.C.; Amorim, M.T.P.; Felgueiras, H.P. Electrospun Nanocomposites Containing Cellulose and Its Derivatives Modified with Specialized Biomolecules for an Enhanced Wound Healing. Nanomaterials 2020, 10, 557. [CrossRef] [PubMed] 
34. Fu, L.-H.; Qi, C.; Ma, M.-G.; Wan, P. Multifunctional cellulose-based hydrogels for biomedical applications. J. Mater. Chem. B 2019, 7, 1541-1562. [CrossRef]

35. Gaspar-Pintiliescu, A.; Stanciuc, A.-M.; Craciunescu, O. Natural composite dressings based on collagen, gelatin and plant bioactive compounds for wound healing: A review. Int. J. Biol. Macromol. 2019, 138, 854-865. [CrossRef]

36. Lin, H.; Cheng, A.W.-M.; Alexander, P.G.; Beck, A.M.; Tuan, R.S. Cartilage Tissue Engineering Application of Injectable Gelatin Hydrogel with In Situ Visible-Light-Activated Gelation Capability in both Air and Aqueous Solution. Tissue Eng. Part A 2014, 20, 2402-2411. [CrossRef]

37. Yang, G.; Lin, H.; Rothrauff, B.B.; Yu, S.; Tuan, R.S. Multilayered Polycaprolactone/Gelatin Fiber-Hydrogel Composite for Tendon Tissue Engineering. Acta Biomater. 2016, 35, 68-76. [CrossRef] [PubMed]

38. Gurumurthy, B.; Janorkar, A.V. Improvements in Mechanical Properties of Collagen-Based Scaffolds for Tissue Engineering. Curr. Opin. Biomed. Eng. 2021, 17, 100253. [CrossRef]

39. Nuñez, S.M.; Guzmán, F.; Valencia, P.; Almonacid, S.; Cárdenas, C. Collagen as a source of bioactive peptides: A bioinformatics approach. Electron. J. Biotechnol. 2020, 48, 101-108. [CrossRef]

40. Hashim, P.; Mohd Ridzwan, M.S.; Bakar, J.; Mat Hashim, D. Collagen in food and beverage industries. Int. Food Res. J. 2015, 22, 1-8.

41. Ferreira, A.M.; Gentile, P.; Chiono, V.; Ciardelli, G. Collagen for bone tissue regeneration. Acta Biomater. 2012, 8, 3191-3200. [CrossRef]

42. Yu, F.; Prashantha, K.; Soulestin, J.; Lacrampe, M.-F.; Krawczak, P. Plasticized-starch/poly(ethylene oxide) blends prepared by extrusion. Carbohydr. Polym. 2013, 91, 253-261. [CrossRef]

43. Theodosopoulos, G.V.; Zisis, C.; Charalambidis, G.; Nikolaou, V.; Coutsolelos, A.G.; Pitsikalis, M. Synthesis, Characterization and Thermal Properties of Poly(ethylene oxide), PEO, Polymacromonomers via Anionic and Ring Opening Metathesis Polymerization. Polymers 2017, 9, 145. [CrossRef] [PubMed]

44. Kundu, J.; Pati, F.; Jeong, Y.H.; Cho, D.-W. Biomaterials for Biofabrication of 3D Tissue Scaffolds. In Biofabrication; Forgacs, G., Sun, W., Eds.; William Andrew Publishing: Norwich, NY, USA, 2013; pp. $23-46$.

45. Wong, R.S.H.; Dodou, K. Effect of Drug Loading Method and Drug Physicochemical Properties on the Material and Drug Release Properties of Poly (Ethylene Oxide) Hydrogels for Transdermal Delivery. Polymer 2017, 9, 286. [CrossRef] [PubMed]

46. Venugopal, J.; Ramakrishna, S. Biocompatible nanofiber matrices for the engineering of a dermal substitute for skin regeneration. Tissue Eng. 2005, 11, 847-854. [CrossRef] [PubMed]

47. Zhong, X.; Ji, C.; Chan, A.K.L.; Kazarian, S.G.; Ruys, A.; Dehghani, F. Fabrication of chitosan/poly( $\varepsilon$-caprolactone) composite hydrogels for tissue engineering applications. J. Mater. Sci. Mater. Med. 2011, 22, 279-288. [CrossRef] [PubMed]

48. Teixeira, M.A.; Amorim, M.T.P.; Felgueiras, H.P. Poly(Vinyl Alcohol)-Based Nanofibrous Electrospun Scaffolds for Tissue Engineering Applications. Polymers 2020, 12, 7. [CrossRef]

49. Manavitehrani, I.; Fathi, A.; Wang, Y.; Maitz, P.; Dehghani, F. Reinforced Poly(Propylene Carbonate) Composite with Enhanced and Tunable Characteristics, an Alternative for Poly(lactic Acid). ACS Appl. Mater. Interfaces 2015, 7, 22421-22430. [CrossRef] [PubMed]

50. Maitz, M.F. Applications of synthetic polymers in clinical medicine. Biosurface Biotribol. 2015, 1, 161-176. [CrossRef]

51. Virlan, M.J.R.; Miricescu, D.; Totan, A.; Greabu, M.; Tanase, C.; Sabliov, C.M.; Caruntu, C.; Calenic, B. Current Uses of Poly(lacticco-glycolic acid) in the Dental Field: A Comprehensive Review. J. Chem. 2015, 2015, 1-12. [CrossRef]

52. Sun, X.; Xu, C.; Wu, G.; Ye, Q.; Wang, C. Poly(Lactic-co-Glycolic Acid): Applications and Future Prospects for Periodontal Tissue Regeneration. Polymer 2017, 9, 189. [CrossRef]

53. Del Prado, A.; Civantos, A.; Martínez-Campos, E.; Levkin, P.A.; Reinecke, H.; Gallardo, A.; Elvira, C. Efficient and Low Cytotoxicity Gene Carriers Based on Amine-Functionalized Polyvinylpyrrolidone. Polymers 2020, 12, 2724. [CrossRef]

54. Voronova, M.; Rubleva, N.; Kochkina, N.; Afineevskii, A.; Zakharov, A.; Surov, O. Preparation and Characterization of Polyvinylpyrrolidone/Cellulose Nanocrystals Composites. Nanomaterials 2018, 8, 1011. [CrossRef] [PubMed]

55. Kurakula, M.; Rao, G.K. Moving polyvinyl pyrrolidone electrospun nanofibers and bioprinted scaffolds toward multidisciplinary biomedical applications. Eur. Polym. J. 2020, 136, 109919. [CrossRef]

56. Mc Gann, M.J.; Higginbotham, C.L.; Geever, L.M.; Nugent, M.J.D. The synthesis of novel pH-sensitive poly(vinyl alcohol) composite hydrogels using a freeze/thaw process for biomedical applications. Int. J. Pharm. 2009, 372, 154-161. [CrossRef]

57. Costa-Júnior, E.S.; Barbosa-Stancioli, E.F.; Mansur, A.A.P.; Vasconcelos, W.L.; Mansur, H.S. Preparation and characterization of chitosan/poly(vinyl alcohol) chemically crosslinked blends for biomedical applications. Carbohydr. Polym. 2009, 76, $472-481$. [CrossRef]

58. Kopeček, J. Hydrogel biomaterials: A smart future? Biomaterials 2007, 28, 5185-5192. [CrossRef]

59. Hwang, M.-R.; Kim, J.O.; Lee, J.H.; Kim, I.Y.; Kim, J.H.; Chang, S.W.; Jin, S.G.; Kim, J.A.; Lyoo, W.S.; Han, S.S.; et al. Gentamicinloaded wound dressing with polyvinyl alcohol/dextran hydrogel: Gel characterization and in vivo healing evaluation. AAPS PharmSciTech 2010, 11, 1092-1103. [CrossRef]

60. Suo, H.; Zhang, D.; Yin, J.; Qian, J.; Wu, Z.L.; Fu, J. Interpenetrating polymer network hydrogels composed of chitosan and photocrosslinkable gelatin with enhanced mechanical properties for tissue engineering. Mater. Sci. Eng. C 2018, 92, 612-620. [CrossRef]

61. Hernández-González, A.C.; Téllez-Jurado, L.; Rodríguez-Lorenzo, L.M. Alginate hydrogels for bone tissue engineering, from injectables to bioprinting: A Review. Carbohydr. Polym. 2019, 229, 115514. [CrossRef] [PubMed] 
62. Li, S.; Dong, S.; Xu, W.; Tu, S.; Yan, L.; Zhao, C.; Ding, J.; Chen, X. Antibacterial Hydrogels. Adv. Sci. 2018, 5, 1700527. [CrossRef] [PubMed]

63. Tsou, Y.-H.; Khoneisser, J.; Huang, P.-C.; Xu, X. Hydrogel as a bioactive material to regulate stem cell fate. Bioact. Mater. 2016, 1, 39-55. [CrossRef] [PubMed]

64. Abbasian, M.; Massoumi, B.; Mohammad-Rezaei, R.; Samadian, H.; Jaymand, M. Scaffolding polymeric biomaterials: Are naturally occurring biological macromolecules more appropriate for tissue engineering? Int. J. Biol. Macromol. 2019, 134, 673-694. [CrossRef] [PubMed]

65. Vasile, C.; Pamfil, D.; Stoleru, E.; Baican, M. New Developments in Medical Applications of Hybrid Hydrogels Containing Natural Polymers. Molecules 2020, 25, 1539. [CrossRef]

66. White, J.C.; Saffe, E.M.; Bhatia, S.R. Alginate/PEO-PPO-PEO Composite Hydrogels with Thermally-Active Plasticity. Biomacromolecules 2013, 14, 4456-4464. [CrossRef]

67. Bai, Z.; Wang, T.; Zheng, X.; Huang, Y.; Chen, Y.; Dan, W. High strength and bioactivity polyvinyl alcohol/collagen composite hydrogel with tannic acid as cross-linker. Polym. Eng. Sci. 2020, 1-10.

68. Ahmed, E.M. Hydrogel: Preparation, characterization, and applications: A review. J. Adv. Res. 2015, 6, 105-121. [CrossRef]

69. Burkert, S.; Schmidt, T.; Gohs, U.; Dorschner, H.; Arndt, K.-F. Cross-linking of poly (N-vinyl pyrrolidone) films by electron beam irradiation. Radiat. Phys. Chem. 2007, 76, 1324-1328. [CrossRef]

70. Yang, L.; Chu, J.S.; Fix, J.A. Colon-specific drug delivery: New approaches and in vitro/in vivo evaluation. Int. J. Pharm. 2002, 235, 1-15. [CrossRef]

71. Teijón, C.; Guerrero, S.; Olmo, R.; Teijón, J.M.; Blanco, M.D. Swelling Properties of Copolymeric Hydrogels of Poly(ethylene glycol) Monomethacrylate and Monoesters of Itaconic Acid for Use in Drug Delivery. J. Biomed. Mater. Res. Part B Appl. Biomater. 2009, 91, 716-726. [CrossRef]

72. Lowman, A.M.; Peppas, N.A. Analysis of the Complexation/Decomplexation Phenomena in Graft Copolymer Networks. Macromolecular 1997, 30, 4959-4965. [CrossRef]

73. Jana, S.; Saha, A.; Nayak, A.K.; Sen, K.K.; Basu, S.K. Aceclofenac-loaded chitosan-tamarind seed polysaccharide interpenetrating polymeric network microparticles. Colloids Surf. B Biointerfaces 2013, 105, 303-309. [CrossRef] [PubMed]

74. Okay, O. Semicrystalline physical hydrogels with shape-memory and self-healing properties. J. Mater. Chem. B 2019, 7, 1581-1596. [CrossRef]

75. BaoLin, G.; MA, P.X. Synthetic biodegradable functional polymers for tissue engineering: A brief review. Sci. China Chem. 2014, $57,490-500$.

76. Iglesias, N.; Galbis, E.; Valencia, C.; Díaz-Blanco, M.J.; Lacroix, B.; De-Paz, M.-V. Biodegradable double cross-linked chitosan hydrogels for drug delivery: Impact of chemistry on rheological and pharmacological performance. Int. J. Biol. Macromol. 2020, 165, 2205-2218. [CrossRef]

77. Kong, H.J.; Kaigler, D.; Kim, K.; Mooney, D.J. Controlling Rigidity and Degradation of Alginate Hydrogels via Molecular Weight Distribution. Biomacromolecules 2004, 5, 1720-1727. [CrossRef]

78. Bouhadir, K.H.; Lee, K.Y.; Alsberg, E.; Damm, K.L.; Anderson, K.W.; Mooney, D.J. Degradation of partially oxidized alginate and its potential application for tissue engineering. Biotechnol. Prog. 2001, 17, 945-950. [CrossRef]

79. West, J.L.; Hubbell, J.A. Polymeric biomaterials with degradation sites for proteases involved in cell migration. Macromolecules 1999, 32, 241-244. [CrossRef]

80. Tanan, W.; Panichpakdee, J.; Saengsuwan, S. Novel Biodegradable Hydrogel Based on Natural Polymers: Synthesis, Characterization, Swelling/Reswelling and Biodegradability. Eur. Polym. J. 2018, 112, 678-687. [CrossRef]

81. Mantha, S.; Pillai, S.; Khayambashi, P.; Upadhyay, A.; Zhang, Y.; Tao, O.; Pham, H.M.; Tran, S.D. Smart Hydrogels in Tissue Engineering and Regenerative Medicine. Materials 2019, 12, 3323. [CrossRef] [PubMed]

82. Fänger, C.; Wack, H.; Ulbricht, M. Macroporous Poly(N-isopropylacrylamide) Hydrogels with Adjustable size "Cut-off” for the Efficient and Reversible Immobilization of Biomacromolecules. Macromol. Biosci. 2006, 6, 393-402. [CrossRef]

83. Sood, N.; Bhardwaj, A.; Mehta, S.; Mehta, A. Stimuli-responsive hydrogels in drug delivery and tissue engineering. Drug Deliv. 2014, 7544, 1-23. [CrossRef] [PubMed]

84. Bag, M.A.; Valenzuela, L.M. Impact of the Hydration States of Polymers on Their Hemocompatibility for Medical Applications: A review. Int. J. Mol. Sci. 2017, 18, 1422. [CrossRef]

85. Gupta, A.; Kowalczuk, M.; Heaselgrave, W.; Britland, S.T.; Martin, C.; Radecka, I. The production and application of hydrogels for wound management: A review. Eur. Polym. J. 2019, 111, 134-151. [CrossRef]

86. Kwon, S.S.; Kong, B.J.; Park, S.N. Physicochemical properties of pH-sensitive hydrogels based on hydroxyethyl cellulosehyaluronic acid and for applications as transdermal delivery systems for skin lesions. Eur. J. Pharm. Biopharm. 2015, 92, 146-154. [CrossRef]

87. Salleh, K.M.; Zakaria, S.; Sajab, M.S.; Gan, S.; Chia, C.H.; Jaafar, S.N.S.; Amran, U.A. Chemically crosslinked hydrogel and its driving force towards superabsorbent behaviour. Int. J. Biol. Macromol. 2018, 118, 1422-1430. [CrossRef]

88. Zhao, Q.S.; Ji, Q.X.; Xing, K.; Li, X.Y.; Liu, C.S.; Chen, X.G. Preparation and characteristics of novel porous hydrogel films based on chitosan and glycerophosphate. Carbohydr. Polym. 2009, 76, 410-416. [CrossRef]

89. Kimura, M.; Fukumoto, K.; Watanabe, J.; Ishihara, K. Hydrogen-bonding-driven spontaneous gelation of water-soluble phospholipid polymers in aqueous medium. J. Biomater. Sci. Polym. Ed. 2004, 15, 631-644. [CrossRef] 
90. Tuncaboylu, D.C.; Sari, M.; Oppermann, W.; Okay, O. Tough and Self-healing Hydrogels Formed via Hydrophobic Interactions. Macromolecules 2011, 44, 4997-5005. [CrossRef]

91. Stenekes, R.J.H.; Talsma, H.; Hennink, W.E. Formation of dextran hydrogels by crystallization. Biomaterials 2001, 22, 1891-1898. [CrossRef]

92. George, J.; Hsu, C.-C.; Nguyen, L.T.B.; Ye, H.; Cui, Z. Neural tissue engineering with structured hydrogels in CNS models and therapies. Biotechnol. Adv. 2019, 42, 1-17. [CrossRef]

93. Czarnecki, S.; Rossow, T.; Seiffert, S. Hybrid Polymer-Network Hydrogels with Tunable Mechanical Response. Polymers 2016, 8, 82. [CrossRef]

94. Hoffman, A.S. Hydrogels for biomedical applications. Adv. Drug Deliv. Rev. 2002, 43, 3-12. [CrossRef]

95. Rosiak, J.M.; Yoshii, F. Hydrogels and their medical applications. Nucl. Instrum. Methods Phys. Res. Sect. B Beam Interact. Mater. Atoms 1999, 151, 56-64. [CrossRef]

96. Zhang, H.; Zhang, F.; Wu, J. Physically crosslinked hydrogels from polysaccharides prepared by freeze-thaw technique. React. Funct. Polym. 2013, 73, 923-928. [CrossRef]

97. Zhong, M.; Liu, Y.-T.; Xie, X.-M. Self-healable, super tough graphene oxide/poly(acrylic acid) nanocomposite hydrogels facilitated by dual cross-linking effects through dynamic ionic interactions. J. Mater. Chem. B 2015, 3, 4001-4008. [CrossRef] [PubMed]

98. Hu, W.; Wang, Z.; Xiao, Y.; Zhanga, S.; Wang, J. Advances in crosslinking strategies of biomedical hydrogels. Biomater. Sci. 2019, 7, 843-855. [CrossRef] [PubMed]

99. Hoare, T.R.; Kohane, D.S. Hydrogels in drug delivery: Progress and challenges. Polymers 2008, 49, 1993-2007. [CrossRef]

100. Abdurrahmanoglu, S.; Can, V.; Okay, O. Design of high-toughness polyacrylamide hydrogels by hydrophobic modification. Polymer 2009, 50, 5449-5455. [CrossRef]

101. Zhang, Y.; Zhao, X.; Yang, W.; Jiang, W.; Chen, F.; Fu, Q. Enhancement of mechanical property and absorption capability of hydrophobically associated polyacrylamide hydrogels by adding cellulose nanofiber. Mater. Res. Express 2020, 7, 015319. [CrossRef]

102. Figueroa-Pizano, M.D.; Vélaz, I.; Peñas, F.J.; Zavala-Rivera, P.; Rosas-Durazo, A.J.; Maldonado-Arce, A.D.; Martínez-Barbosa, M.E. Effect of freeze-thawing conditions for preparation of chitosan-poly (vinyl alcohol) hydrogels and drug release studies. Carbohydr. Polym. 2018, 195, 476-485. [CrossRef] [PubMed]

103. Ricciardi, R.; Auriemma, F.; De Rosa, C.; Lauprêtre, F. X-ray Diffraction Analysis of Poly (vinyl alcohol) Hydrogels, Obtained by Freezing and Thawing Techniques. Macromolecules 2004, 37, 1921-1927. [CrossRef]

104. Lotfipour, F.; Alami-Milani, M.; Salatin, S.; Hadavi, A.; Jelvehgari, M. Freeze-thaw- induced cross-linked PVA/chitosan for oxytetracycline-loaded wound dressing: The experimental design and optimization. Res. Pharm. Sci. 2019, 14, 175-189.

105. Sabnis, A.; Rahimi, M.; Chapman, C.; Nguyen, K.T. Cytocompatibility studies of an in situ photopolymerized thermoresponsive hydrogel nanoparticle system using human aortic smooth muscle cells. J. Biomed. Mater. Res. Part A 2008, 91, 52-59.

106. Han, W.T.; Jang, T.; Chen, S.; Chong, L.S.H.; Jung, H.; Song, J. Improved cell viability for large-scale biofabrication with photo-crosslinkable hydrogel systems through a dual-photoinitiator approach. Biomater. Sci. 2020, 8, 450-461. [CrossRef]

107. Zhao, L.; Li, X.; Zhao, J.; Ma, S.; Ma, X.; Fan, D.; Zhu, C.; Liu, Y. A novel smart injectable hydrogel prepared by microbial transglutaminase and human-like collagen: Its characterization and biocompatibility. Mater. Sci. Eng. C 2016, 68, 317-326. [CrossRef]

108. Ren, K.; He, C.; Cheng, Y.; Li, G.; Chen, X. Injectable enzymatically crosslinked hydrogels based on a poly(L-glutamic acid) graft copolymer. Polym. Chem. 2014, 5, 5069-5076. [CrossRef]

109. Teixeira, L.S.M.; Feijen, J.; Van Blitterswijk, C.A.; Dijkstra, P.J.; Karperien, M. Enzyme-catalyzed crosslinkable hydrogels: Emerging strategies for tissue engineering. Biomaterials 2012, 33, 1281-1290. [CrossRef] [PubMed]

110. Kanafi, N.M.; Rahman, N.A.; Rosdi, N.H. Citric acid cross-linking of highly porous carboxymethyl cellulose poly(ethylene oxide) composite hydrogel films for controlled release applications. Mater. Today Proc. 2019, 7, 721-731. [CrossRef]

111. Dimida, S.; Demitri, C.; De Benedictis, V.M.; Scalera, F.; Gervaso, F.; Sannino, A. Genipin-cross-linked chitosan-based hydrogels: Reaction kinetics and structure-related characteristics. J. Appl. Polym. Sci. 2015, 132, 1-8. [CrossRef]

112. Lai, J.-Y. Solvent Composition is Critical for Carbodiimide Cross-Linking of Hyaluronic Acid as an Ophthalmic Biomaterial. Materials 2012, 5, 1986-2002. [CrossRef]

113. Jin, R.; Teixeira, L.S.M.; Krouwels, A.; Dijkstra, P.J.; Van Blitterswijk, C.A.; Karperien, M.; Feijen, J. Synthesis and characterization of hyaluronic acid-poly(ethylene glycol) hydrogels via Michael addition: An injectable biomaterial for cartilage repair. Acta Biomater. 2010, 6, 1968-1977. [CrossRef] [PubMed]

114. Parhi, R. Cross-Linked Hydrogel for Pharmaceutical Applications: A Review. Adv. Pharm. Bull. 2017, 7, 515-530. [CrossRef] [PubMed]

115. Martinez-Martinez, M.; Rodriguez-Berna, G.; Gonzalez-Alvarez, I.; Hernández, M.J.; Corma, A.; Bermejo, M.; Merino, V.; Gonzalez-Alvarez, M. Ionic hydrogel based on chitosan crosslinked with 6-Phosphogluconic Trisodium salt as a drug delivery system. Biomacromolecules 2018, 19, 1294-1304. [CrossRef] [PubMed]

116. Wang, Y.; Ma, M.; Wang, J.; Zhang, W.; Lu, W.; Gao, Y.; Zhang, B.; Guo, Y. Development of a Photo-Crosslinking, Biodegradable GelMA/PEGDA Hydrogel for Guided Bone Regeneration Materials. Materials 2018, 11, 1345. [CrossRef] [PubMed] 
117. Choi, J.H.; Choi, O.K.; Lee, J.; Noh, J.; Lee, S.; Park, A.; Rim, M.A.; Reis, R.L.; Khang, G. Evaluation of double network hydrogel of poloxamer-heparin/gellan gum for bone marrow stem cells delivery carrier. Colloids Surfaces B Biointerfaces 2019, 181, 879-889. [CrossRef]

118. Masruchin, N.; Park, B.-D.; Causin, V. Influence of sonication treatment on supramolecular cellulose microfibril-based hydrogels induced by ionic interaction. J. Ind. Eng. Chem. 2015, 29, 265-272. [CrossRef]

119. Liu, T.; Jiao, C.; Peng, X.; Chen, Y.-N.; Chen, Y.; He, C.; Liu, R.; Wang, H. Super-strong and tough poly(vinyl alcohol)/poly(acrylic acid) hydrogels reinforced by hydrogen bonding. J. Mater. Chem. B 2018, 6, 8105-8114. [CrossRef]

120. Ye, X.; Li, X.; Shen, Y.; Chang, G.; Yang, J.; Gu, Z. Self-healing pH-sensitive cytosine- and guanosine-modified hyaluronic acid hydrogels via hydrogen bonding. Polymer 2017, 108, 348-360. [CrossRef]

121. Ahmed, A.S.; Mandal, U.K.; Taher, M.; Susanti, D.; Jaffri, J.M. PVA-PEG physically cross-linked hydrogel film as a wound dressing: Experimental design and optimization. Pharm. Dev. Technol. 2018, 23, 751-760. [CrossRef]

122. Hurtado, M.M.; de Vries, E.G.; Zeng, X.; van der Heide, E. A tribo-mechanical analysis of PVA-based building-blocks for implementation in a 2-layered skin model. J. Mech. Behav. Biomed. Mater. 2016, 62, 319-332. [CrossRef]

123. Nachlas, A.L.Y.; Li, S.; Jha, R.; Singh, M.; Xu, C.; Davis, M.E. Human iPSC-derived mesenchymal stem cells matured into valve interstitial- like cells using PEGDA hydrogels. Acta Biomater. 2018, 71, 235-246. [CrossRef]

124. Yoon, H.J.; Shin, S.R.; Cha, J.M.; Lee, S.H.; Kim, J.H.; Do, J.T.; Song, H.; Bae, H. Cold Water Fish Gelatin Methacryloyl Hydrogel for Tissue Engineering Application. PLoS ONE 2016, 11, 1-18. [CrossRef] [PubMed]

125. Hasturk, O.; Jordan, K.E.; Choi, J.; Kaplan, D.L. Enzymatically crosslinked silk and silk-gelatin hydrogels with tunable gelation kinetics, mechanical properties and bioactivity for cell culture and encapsulation. Biomaterials 2020, 232, 119720. [CrossRef]

126. Besser, R.R.; Bowles, A.C.; Alassaf, A.; Carbonero, D.; Claure, I.; Jones, E.; Reda, J.; Wubker, L.; Batchelor, W.; Ziebarth, N.; et al. Enzymatically crosslinked gelatin-laminin hydrogels for applications in neuromuscular tissue engineering. Biomater. Sci. 2020, 8, 591-606. [CrossRef] [PubMed]

127. Ubaid, M.; Murtaza, G. Fabrication and characterization of genipin cross-linked chitosan/gelatin hydrogel for pH-sensitive, oral delivery of metformin with an application of response surface methodology. Int. J. Biol. Macromol. 2018, 114, $1174-1185$. [CrossRef] [PubMed]

128. Martínez-Mejía, G.; Vázquez-Torres, N.A.; Castell-Rodríguez, A.; del Río, J.M.; Corea, M.; Jiménez-Juárez, R. Synthesis of new chitosan-glutaraldehyde scaffolds for tissue engineering using schiff reactions. Colloids Surfaces A Physicochem. Eng. Asp. 2019, 579, 123658. [CrossRef]

129. Wang, G.; Wang, X.; Huang, L. Feasibility of chitosan-alginate (Chi-Alg) hydrogel used as scaffold for neural tissue engineering: A pilot study in vitro. Biotechnol. Biotechnol. Equip. 2017, 31, 766-773. [CrossRef]

130. Seera, S.D.K.; Kundu, D.; Banerjee, T. Physical and chemical crosslinked microcrystalline cellulose-polyvinyl alcohol hydrogel: Freeze-thaw mediated synthesis, characterization and in vitro delivery of 5- fluorouracil. Cellulose 2020, 27, 6521-6535. [CrossRef]

131. Marin, E.; Boschetto, F.; Pezzotti, G. Biomaterials and biocompatibility: An historical overview. J. Biomed. Mater. Res. Part A 2020, 108, 1617-1633. [CrossRef]

132. Moulherat, C.; Tengberg, M.; Haquet, J.F.; Mille, B. First evidence of cotton at Neolithic Mehrgarh, Pakistan: Analysis of Mineralized Fibres from a Copper Bead. J. Archaeol. Sci. 2002, 29, 1393-1401. [CrossRef]

133. Holland, C.; Numata, K.; Rnjak-Kovacina, J.; Seib, F.P. The Biomedical Use of Silk: Past, Present, Future. Adv. Healthc. Mater. 2018, 8, 1800465. [CrossRef]

134. Bari, E.; Morrell, J.J.; Sistani, A. Durability of natural/synthetic/biomass fiber-based polymeric composites: Laboratory and field tests. In Durability and Life Prediction in Biocomposites, Fibre-Reinforced Composites and Hybrid Composites; Jawaid, M., Thariq, M., Saba, N., Eds.; Woodhead Publishing: Cambridge, UK, 2019; pp. 15-26.

135. Tavares, T.D.; Antunes, J.C.; Ferreira, F.; Felgueiras, H.P. Biofunctionalization of natural Fiber-Reinforced Biocomposites for Biomedical Applications. Biomolecules 2020, 10, 148. [CrossRef]

136. Pankongadisak, P.; Sangklin, S.; Chuysinuan, P.; Suwantong, O.; Supaphol, P. The use of electrospun curcumin-loaded poly(Llactic acid) fiber mats as wound dressing materials. J. Drug Deliv. Sci. Technol. 2019, 53, 101121. [CrossRef]

137. Heydari, Z.; Mohebbi-Kalhori, D.; Afarani, M.S. Engineered electrospun polycaprolactone (PCL)/octacalcium phosphate (OCP) scaffold for bone tissue engineering. Mater. Sci. Eng. C 2017, 81, 127-132. [CrossRef] [PubMed]

138. Wang, J.; Windbergs, M. Controlled dual drug release by coaxial electrospun fibers-Impact of the core fluid on drug encapsulation and release. Int. J. Pharm. 2018, 556, 363-371. [CrossRef] [PubMed]

139. Gurunathan, T.; Mohanty, S.; Nayak, S.K. A review of the Recent Developments in Biocomposites Based on Natural Fibres and Their Application Perspectives. Compos. Part A Appl. Sci. Manuf. 2015, 77, 1-25. [CrossRef]

140. Hao, L.C.; Sapuan, S.M.; Hassan, M.R.; Sheltami, R.M. Natural fiber reinforced vinyl polymer composites. In Natural Fibre Reinforced Vinyl Ester and Vinyl Polymer Composites; Sapuan, S.M., Ismail, H., Zainudin, E.S., Eds.; Woodhead Publishing: Cambridge, UK, 2018; pp. 27-70.

141. Balla, V.K.; Kate, K.H.; Satyavolu, J.; Singh, P.; Tadimeti, J.G.D. Additive manufacturing of natural fiber reinforced polymer composites: Processing and prospects. Compos. Part B Eng. 2019, 174, 106956. [CrossRef]

142. Fidelis, M.E.A.; Pereira, T.V.C.; Gomes, O.D.F.M.; de Andrade Silva, F.; Filho, R.D.T. The effect of fiber morphology on the tensile strength of natural fibers. Integr. Med. Res. 2013, 2, 149-157. 
143. Rahman, R.; Putra, S.Z.F.S. Tensile properties of natural and synthetic fiber-reinforced polymer composites. In Mechanical and Physical Testing of Biocomposites, Fibre-Reinforced Composites and Hybrid Composites; Jawaid, M., Thariq, M., Saba, N., Eds.; Woodhead Publishing: Cambridge, UK, 2019; pp. 81-102.

144. Sanjay, M.R.; Madhu, P.; Jawaid, M.; Senthamaraikannan, P.; Senthil, S.; Pradeep, S. Characterization and Properties of Natural Fiber Polymer Composites: A Comprehensive Review. J. Clean. Prod. 2017, 172, 566-581. [CrossRef]

145. Bannow, J.; Benjamins, J.-W.; Wohlert, J.; Löbmann, K.; Svagan, A.J. Solid nanofoams based on cellulose nanofibers and indomethacin-the effect of processing parameters and drug content on material structure. Int. J. Pharm. 2017, 526, 291-299. [CrossRef]

146. Doench, I.; Torres-Ramos, M.E.W.; Montembault, A.; de Oliveira, P.N.; Halimi, C.; Viguier, E.; Heux, L.; Siadous, R.; Thiré, R.M.S.M.; Osorio-Madrazo, A. Injectable and Gellable Chitosan Formulations Filled with Cellulose Nanofibers for Intervertebral Disc Tissue Engineering. Polymers 2018, 10, 1202. [CrossRef]

147. Ramamoorthy, S.K.; Skrifvars, M.; Persson, A. A Review of Natural Fibers Used in Biocomposites: Plant, Animal and Regenerated Cellulose Fibers. Polym. Rev. 2015, 55, 107-161. [CrossRef]

148. Costa, F.; Silva, R.; Boccaccini, A.R. Fibrous protein-based biomaterials (silk, keratin, elastin, and resilin proteins) for tissue regeneration and repair. In Peptides and Proteins as Biomaterials for Tissue Regeneration and Repair; Barbosa, M.A., Martins, M.C.L., Eds.; Woodhead Publishing: Cambridge, UK, 2018; pp. 175-204.

149. McLellan, J.; Thornhill, S.G.; Shelton, S.; Kumar, M. Keratin-Based Biofilms, Hydrogels, and Biofibers. In Keratin as a Protein Biopolymer; Sharma, S., Kumar, A., Eds.; Springer: Cham, Switzerland, 2019; pp. 187-200.

150. Koh, L.-D.; Cheng, Y.; Teng, C.-P.; Khin, Y.-W.; Loh, X.-J.; Tee, S.-Y.; Low, M.; Ye, E.; Yu, H.-D.; Zhang, Y.-W.; et al. Structures, mechanical properties and applications of silk fibroin materials. Prog. Polym. Sci. 2015, 46, 86-110. [CrossRef]

151. Babu, K.M. Natural Textile Fibres: Animal and Silk Fibres. In Textiles and Fashion; Sinclair, R., Ed.; Woodhead Publishing: Cambridge, UK, 2015; pp. 57-78.

152. Mahltig, B. Introduction to inorganic fibers. In Inorganic and Composite Fibers: Production, Properties, and Applications; Mahltig, B., Kyosev, Y., Eds.; Woodhead Publishing: Cambridge, UK, 2018; pp. 1-29.

153. Bhat, G.; Kandagor, V. Synthetic polymer fibers and their processing requirements. In Advances in Filament Yarn Spinning of Textiles and Polymers; Zhang, D., Ed.; Woodhead Publishing: Cambridge, UK, 2014; pp. 3-30.

154. Ivorra-Martinez, J.; Verdu, I.; Fenollar, O.; Sanchez-Nacher, L.; Balart, R.; Quiles-Carrillo, L. Manufacturing and Properties of Binary Blend from Bacterial Polyester Poly(3-hydroxybutyrate-co-3-hydroxyhexanoate) and Poly(caprolactone) with Improved Toughness. Polymers 2020, 12, 1118. [CrossRef]

155. Gupta, B.; Revagade, N.; Hilborn, J. Poly(lactic acid) fiber: An overview. Prog. Polym. Sci. 2007, 32, 455-482. [CrossRef]

156. McNeil, S.E.; Griffiths, H.R.; Perrie, Y. Polycaprolactone Fibres as a Potential Delivery System for Collagen to Support Bone Regeneration. Curr. Drug Deliv. 2011, 8, 448-455. [CrossRef]

157. Hu, W.-W.; Lin, C.-H.; Hong, Z.-J. The enrichment of cancer stem cells using composite alginate/polycaprolactone nanofibers. Carbohydr. Polym. 2018, 206, 70-79. [CrossRef] [PubMed]

158. Levengood, S.L.; Erickson, A.E.; Chang, F.; Zhang, M. Chitosan-poly(caprolactone) nanofibers for skin repair. J. Mater. Chem. B 2017, 5, 1822-1833. [CrossRef] [PubMed]

159. Kan, Y.; Salimon, A.I.; Korsunsky, A.M. On the electrospinning of nanostructured collagen-PVA fiber mats. Mater. Today Proc. 2020, 33, 2013-2019. [CrossRef]

160. Naskar, D.; Ghosh, A.K.; Mandal, M.; Das, P.; Nandi, S.K.; Kundu, S.C. Dual growth factor loaded nonmulberry silk fibroin/carbon nanofiber composite 3D scaffolds for in vitro and in vivo bone regeneration. Biomaterials 2017, 136, 67-85. [CrossRef]

161. Latif, R.; Wakeel, S.; Khan, N.Z.; Siddiquee, A.N.; Verma, S.L.; Khan, Z.A. Surface treatments of plant fibers and their effects on mechanical properties of fiber-reinforced composites: A review. J. Reinf. Plast. Compos. 2018, 38, 15-30. [CrossRef]

162. Sanjay, M.R.; Arpitha, G.R.; Naik, L.L.; Gopalakrisha, K.; Yogesha, B. Applications of Natural Fibers and Its Composites: An Overview. Nat. Resour. 2016, 7, 108-114. [CrossRef]

163. Peças, P.; Carvalho, H.; Salman, H.; Leite, M. Natural Fibre Composites and Their Applications: A Review. J. Compos. Sci. 2018, 2, 66. [CrossRef]

164. Padil, V.V.T.; Cheong, J.Y.; KP, A.; Makvandi, P.; Zare, E.N.; Torres-Mendieta, R.; Wacławek, S.; Černík, M.; Kim, I.D.; Varma, R.S. Electrospun fibers based on carbohydrate gum polymers and their multifaceted applications. Carbohydr. Polym. 2020, $247,116705$. [CrossRef] [PubMed]

165. Liang, D.; Hsiao, B.S.; Chu, B. Functional electrospun nanofibrous scaffolds for biomedical applications. Adv. Drug Deliv. Rev. 2007, 59, 1392-1412. [CrossRef] [PubMed]

166. Felgueiras, H.P.; Amorim, M.T.P. Functionalization of electrospun polymeric wound dressings with antimicrobial peptides. Colloids Surfaces B Biointerfaces 2017, 156, 133-148. [CrossRef]

167. Shabani, I.; Haddadi-Asl, V.; Seyedjafari, E.; Soleimani, M. Cellular infiltration on nanofibrous scaffolds using a modified electrospinning technique. Biochem. Biophys. Res. Commun. 2012, 423, 50-54. [CrossRef] [PubMed]

168. Kumbar, S.G.; James, R.; Nukavarapu, S.P.; Laurencin, C.T. Electrospun nanofiber scaffolds: Engineering soft tissues. Biomed. Mater. 2008, 3, 034002. [CrossRef] [PubMed]

169. Al-Hazeem, N.Z.A. Nanofibers and Electrospinning Method. In Novel Nanomaterials-Synthesis and Applications. Kyzas, G., Mitropoulos, A.C., Eds.; IntechOpen: London, UK, 2018; pp. 191-210. 
170. Greiner, A.; Wendorff, J.H. Electrospinning: A fascinating Method for the Preparation of Ultrathin Fibers. Angew. Chemie Int. Ed. 2007, 46, 5670-5703. [CrossRef] [PubMed]

171. Puppi, D.; Chiellini, F. Wet-spinning of Biomedical Polymers: From Single Fibers Production to Additive Manufacturing of 3D Scaffolds. Polym. Int. 2017, 66, 1690-1696. [CrossRef]

172. Ozipek, B.; Karakas, H. Wet spinning of synthetic polymer fibers. In Advances in Filament Yarn Spinning of Textiles and Polymers; Zhang, D., Ed.; Woodhead Publishing: Cambridge, UK, 2014; pp. 174-186.

173. Tronci, G.; Kanuparti, R.S.; Arafat, M.T.; Yin, J.; Wood, D.J.; Russell, S.J. Wet-spinnability and crosslinked fibre properties of two collagen polypeptides with varied molecular weight. Int. J. Biol. Macromol. 2015, 81, 112-120. [CrossRef] [PubMed]

174. Bonhomme, O.; Leng, J.; Colin, A. Microfluidic wet-spinning of alginate microfibers: A theoretical analysis of fiber formation. Soft Matter 2012, 8, 10641-10649. [CrossRef]

175. Jia, J.; Yao, D.; Wang, Y. Melt spinning of continuous fibers by cold air attenuation I: Experimental studies. Text. Res. J. 2014, 84, 593-603. [CrossRef]

176. Gajjar, C.R.; King, M.W. Resorbable Fiber-Forming Polymers for Biotextile Applications; Springer International Publishing: New York, NY, USA, 2014.

177. Imura, Y.; Hogan, R.M.C.; Jaffe, M. Dry spinning of synthetic polymer fibers. In Advances in Filament Yarn Spinning of Textiles and Polymers; Zhang, D., Ed.; Woodhead Publishing: Cambridge, UK, 2014; pp. 187-202.

178. Lee, S.-H.; Park, S.-Y.; Choi, J.-H. Fiber Formation and Physical Properties of Chitosan Fiber Crosslinked by Epichlorohydrin in a Wet Spinning System: The effect of the Concentration of the Crosslinking Agent Epichlorohydrin. J. Appl. Polym. Sci. 2004, 92, 2054-2062. [CrossRef]

179. Azimi, B.; Maleki, H.; Zavagna, L.; la Ossa, J.G.D.; Linari, S.; Lazzeri, A.; Danti, S. Bio-Based Electrospun Fibers for Wound Healing. J. Funct. Biomater. 2020, 11, 67. [CrossRef]

180. Mirzaei, B.E.; Ramazani, S.A.A.; Shafiee, M.; Danaei, M. Studies on Glutaraldehyde Crosslinked Chitosan Hydrogel Properties for Drug Delivery Systems. Int. J. Polym. Mater. Polym. Biomater. 2013, 62, 605-611. [CrossRef]

181. Blakeney, B.A.; Tambralli, A.; Anderson, J.M.; Andukuri, A.; Lim, D.-J.; Dean, D.R.; Jun, H.-W. Cell Infiltration and Growth in a Low Density, Uncompressed Three-Dimensional Electrospun Nanofibrous Scaffold. Biomaterials 2012, 32, 1583-1590. [CrossRef] [PubMed]

182. Kim, J.H.; Choi, Y.-J.; Yi, H.-G.; Wang, J.H.; Cho, D.-W.; Jeong, Y.H. A cell-laden hybrid fiber/hydrogel composite for ligament regeneration with improved cell delivery and infiltration. Biomed. Mater. 2017, 12, 055010. [CrossRef] [PubMed]

183. Jordan, A.M.; Kim, S.-E.; Van de Voorde, K.; Pokorski, J.K.; Korley, L.T.J. In Situ Fabrication of Fiber Reinforced Three-Dimensional Hydrogel Tissue Engineering Scaffolds. ACS Biomater. Sci. Eng. 2017, 3, 1869-1879. [CrossRef]

184. Kong, B.; Chen, Y.; Liu, R.; Liu, X.; Liu, C.; Shao, Z.; Xiong, L.; Liu, X.; Sun, W.; Mi, S. Fiber reinforced GelMA hydrogel to induce the regeneration of corneal stroma. Nat. Commun. 2020, 11, 1435. [CrossRef]

185. Sheffield, C.; Meyers, K.; Johnson, E.; Rajachar, R.M. Application of Composite Hydrogels to Control Physical Properties in Tissue Engineering and Regenerative Medicine. Gels 2018, 4, 51. [CrossRef]

186. Regev, O.; Reddy, C.S.; Nseir, N.; Zussman, E. Hydrogel Reinforced by Short Albumin Fibers: Mechanical Characterization and Assessment of Biocompatibility. Macromol. Mater. Eng. 2012, 298, 283-291. [CrossRef]

187. Tonsomboon, K.; Oyen, M.L. Composite electrospun gelatin fiber-alginate gel scaffolds for mechanically robust tissue engineered cornea. J. Mech. Behav. Biomed. Mater. 2013, 21, 185-194. [CrossRef]

188. Mohabatpour, F.; Karkhaneh, A.; Sharifi, A.M. A hydrogel/fiber composite scaffold for chondrocyte encapsulation in cartilage tissue regeneration. RSC Adv. 2016, 6, 83135-83145. [CrossRef]

189. Xu, W.; Ma, J.; Jabbari, E. Material properties and osteogenic differentiation of marrow stromal cells on fiber-reinforced laminated hydrogel nanocomposites. Acta Biomater. 2010, 6, 1992-2002. [CrossRef] [PubMed]

190. McMahon, R.E.; Qu, X.; Jimenez-Vergara, A.C.; Bashur, C.A.; Guelcher, S.A.; Goldstein, A.S.; Hahn, M.S. Hydrogel-Electrospun Mesh Composites for Coronary Artery Bypass Grafts. Tissue Eng. Part C 2011, 17, 451-461. [CrossRef] [PubMed]

191. Li, X.; Cho, B.; Martin, R.; Seu, M.; Zhang, C.; Zhou, Z.; Choi, J.S.; Jiang, X.; Chen, L.; Walia, G.; et al. Nanofiber-hydrogel composite-mediated angiogenesis for soft tissue reconstruction. Sci. Transl. Med. 2019, 11, eaau6210. [CrossRef] [PubMed]

192. Ekaputra, A.K.; Prestwich, G.D.; Cool, S.M.; Hutmacher, D.W. The three-dimensional vascularization of growth factor-releasing hybrid scaffold of poly (E-caprolactone )/collagen fibers and hyaluronic acid hydrogel. Biomaterials 2011, 32, 8108-8117. [CrossRef] [PubMed]

193. Han, N.; Johnson, J.; Lannutti, J.J.; Winter, J.O. Hydrogel-electrospun fiber composite materials for hydrophilic protein release. J. Control. Release 2012, 158, 165-170. [CrossRef] [PubMed]

194. Klicova, M.; Klapstova, A.; Chvojka, J.; Koprivova, B.; Jencova, V.; Horakova, J. Novel double-layered planar scaffold combining electrospun PCL fibers and PVA hydrogels with high shape integrity and water stability. Mater. Lett. 2020, 263, 127281. [CrossRef]

195. Tonsomboon, K.; Butcher, A.L.; Oyen, M.L. Strong and tough nanofibrous hydrogel composites based on biomimetic principles. Mater. Sci. Eng. C 2016, 72, 220-227. [CrossRef] [PubMed]

196. Jang, J.; Lee, J.; Seol, Y.-J.; Jeong, Y.H.; Cho, D.-W. Improving mechanical properties of alginate hydrogel by reinforcement with ethanol treated polycaprolactone nanofibers. Compos. Part B 2013, 45, 1216-1221. [CrossRef]

197. Khorshidi, S.; Solouk, A.; Mirzadeh, H.; Mazinani, S.; Lagaron, J.M.; Shari, S.; Ramakrishna, S. A review of key challenges of electrospun scaffolds for tissue-engineering applications. J. Tissue Eng. Regen. Med. 2015, 10, 715-738. [CrossRef] [PubMed] 
198. Papaparaskeva, G.; Louca, M.; Voutouri, C.; Tanasă, E.; Stylianopoulos, T.; Krasia-Christoforou, T. Amalgamated Fiber/Hydrogel Composites Based on Semi-Interpenetrating Polymer Networks and Electrospun Nanocomposite Fibrous Mats. Eur. Polym. J. 2020, 140, 110041. [CrossRef]

199. Hsieh, A.; Zahir, T.; Lapitsky, Y.; Amsden, B.; Wan, W.; Shoichet, M.S. Hydrogel/electrospun fiber composites influence neural stem/progenitor cell fate. Soft Matter 2010, 6, 2227-2237. [CrossRef]

200. Ekaputra, A.K.; Prestwich, G.D.; Cool, S.M.; Hutmacher, D.W. Combining Electrospun Scaffolds with Electrosprayed Hydrogels Leads to Three-Dimensional Cellularization of Hybrid Constructs. Biomacromolecules 2008, 9, 2097-2103. [CrossRef] [PubMed]

201. Thorvaldsson, A.; Silva-Correia, J.; Oliveira, J.M.; Reis, R.L.; Gatenholm, P.; Walkenström, P. Development of Nanofiber-Reinforced Hydrogel Scaffolds for Nucleus Pulposus Regeneration by a Combination of Electrospinning and Spraying Technique. J. Appl. Polym. Sci. 2013, 128, 1158-1163. [CrossRef]

202. Li, J.; Pan, K.; Tian, H.; Yin, L. The Potential of Electrospinning/Electrospraying Technology in the Rational Design of Hydrogel Structures. Macromol. Mater. Eng. 2020, 2000285, 1-26. [CrossRef]

203. Wang, J.-Y.; Wang, K.; Gu, X.; Luo, Y. Polymerization of Hydrogel Network on Microfiber Surface: Synthesis of Hybrid Water-Absorbing Matrices for Biomedical Applications. ACS Biomater. Sci. Eng. 2016, 6, 887-892. [CrossRef]

204. Huang, Y.; Li, X.; Lu, Z.; Zhang, H.; Huang, J.; Yan, K.; Wang, D. Nanofiber-reinforced bulk hydrogel: Preparation and structural, mechanical and biological properties. J. Mater. Chem. B 2020, 8, 9794-9803. [CrossRef]

205. Lin, S.; Cao, C.; Wang, Q.; Gonzalez, M.; Dolbow, J.E.; Zhao, X. Design of stiff, tough and stretchy hydrogel composites via nanoscale hybrid crosslinking and macroscale fiber reinforcement. Soft Matter 2014, 10, 7519-7527. [CrossRef] [PubMed]

206. Li, D.; Ye, Y.; Li, D.; Li, X.; Mu, C. Biological properties of dialdehyde carboxymethyl cellulose crosslinked gelatin-PEG composite hydrogel fibers for wound dressings. Carbohydr. Polym. 2015, 137, 508-514. [CrossRef] [PubMed]

207. Patel, M.; Koh, W.-G. Composite Hydrogel of Methacrylated Hyaluronic Acid and Fragmented Polycaprolactone Nanofiber for Osteogenic Differentiation of Adipose-Derived Stem Cells. Pharmaceutics 2020, 12, 902. [CrossRef] [PubMed]

208. Ahadi, F.; Khorshidi, S.; Karkhaneh, A. A hydrogel/fiber scaffold based on silk fibroin/oxidized pectin with sustainable release of vancomycin hydrochloride. Eur. Polym. J. 2019, 118, 265-274. [CrossRef]

209. Eslami, M.; Vrana, N.E.; Zorlutuna, P.; Sant, S.; Jung, S.; Masoumi, N.; Ramazan Ali, Khavari-Nejad; Javadi, G.; Khademhosseini, A. Fiber-reinforced hydrogel scaffolds for heart valve tissue engineering. J. Biomater. Appl. 2014, 29, 399-410. [CrossRef] [PubMed]

210. Goldberg, S.R.; Diegelmann, R.F. What Makes Wounds Chronic. Surg. Clin. N. Am. 2020, 100, 681-693. [CrossRef] [PubMed]

211. Ambekar, R.S.; Kandasubramanian, B. Advancements in nanofibers for wound dressing: A review. Eur. Polym. J. 2019, 117, 304-336. [CrossRef]

212. Radhakumary, C.; Antonty, M.; Sreenivasan, K. Drug loaded thermoresponsive and cytocompatible chitosan based hydrogel as a potential wound dressing. Carbohydr. Polym. 2011, 83, 705-713. [CrossRef]

213. Abbas, M.; Uçkay, I.; Lipsky, B.A. In diabetic foot infections antibiotics are to treat infection, not to heal wounds. Expert Opin. Pharmacother. 2015, 16, 821-832. [CrossRef]

214. Rubio-Elizalde, I.; Bernáldez-Sarabia, J.; Moreno-Ulloa, A.; Vilanova, C.; Juárez, P.; Licea-Navarro, A.; Castro-Cesenã, A.B. Scaffolds based on alginate-PEG methyl ether methacrylate-Moringa oleifera-Aloe vera for wound healing applications. Carbohydr. Polym. 2018, 206, 455-467. [CrossRef]

215. Joseph, B.; Augustine, R.; Kalarikkal, N.; Thomas, S.; Seantier, B.; Grohens, Y. Recent advances in electrospun polycaprolactone based scaffolds for wound healing and skin bioengineering applications. Mater. Today Commun. 2019, 19, 319-335. [CrossRef]

216. Felgueiras, H.P.; Teixeira, M.A.; Tavares, T.D.; Homem, N.C.; Zille, A.; Amorim, M.T.P. Antimicrobial action and clotting time of thin, hydrated poly(vinyl alcohol )/cellulose acetate fi lms functionalized with LL37 for prospective wound-healing applications. J. Appl. Polym. Sci. 2019, 138, 48626.

217. Zhao, X.; Sun, X.; Yildirimer, L.; Lang, Q.; Lin, Z.Y.; Zheng, R.; Zhang, Y.; Cui, W.; Annabi, N.; Khademhosseini, A. Cell infiltrative hydrogel fibrous scaffolds for accelerated wound healing. Acta Biomater. 2016, 49, 66-77. [CrossRef] [PubMed]

218. Chen, X.; Lu, B.; Zhou, D.; Shao, M.; Xu, W.; Zhou, Y. Photocrosslinking maleilated hyaluronate/methacrylated poly(vinyl alcohol) nanofibrous mats for hydrogel wound dressings. Int. J. Biol. Macromol. 2019, 155, 903-910. [CrossRef] [PubMed]

219. Lutolf, M.P.; Hubbell, J.A. Synthetic biomaterials as instructive extracellular microenvironments for morphogenesis in tissue engineering. Nat. Biotechonol. 2005, 23, 47-55. [CrossRef] [PubMed]

220. Schulte, V.A.; Hahn, K.; Dhanasingh, A.; Heffels, K.-H.; Groll, J. Hydrogel-fibre composites with independent control over cell adhesion to gel and fibres as an integral approach towards a biomimetic artificial ECM. Biofabrication 2014, 6, 024106. [CrossRef]

221. Bonnans, C.; Chou, J.; Werb, Z. Remodelling the extracellular matrix in development and disease. Nat. Rev. Mol. Cell Biol. 2014, 15, 786-801. [CrossRef] [PubMed]

222. Franco, R.A.; Nguyen, T.H.; Lee, B.-T. Preparation and characterization of electrospun PCL/PLGA membranes and chitosan/gelatin hydrogels for skin bioengineering applications. J. Mater. Sci. Mater. Med. 2011, 22, 2207-2218. [CrossRef]

223. Sun, X.; Lang, Q.; Zhang, H.; Cheng, L.; Zhang, Y.; Pan, G. Electrospun Photocrosslinkable Hydrogel Fibrous Scaffolds for Rapid In Vivo Vascularized Skin Flap Regeneration. Adv. Funct. Mater. 2016, 27, 1604617. [CrossRef]

224. Contardi, M.; Kossyvaki, D.; Picone, P.; Summa, M.; Guo, X.; Heredia-Guerrero, J.A.; Giacomazza, D.; Carzino, R.; Goldoni, L.; Scoponi, G.; et al. Electrospun Polyvinylpyrrolidone (PVP) hydrogels containing hydroxycinnamic acid derivatives as potential wound dressings. Chem. Eng. J. 2020, 409, 128144. [CrossRef] 
225. Azarniya, A.; Tamjid, E.; Eslahi, N.; Simchi, A. Modification of bacterial cellulose/keratin nanofibrous mats by a tragacanth gum-conjugated hydrogel for wound healing. Int. J. Biol. Macromol. 2019, 134, 280-289. [CrossRef]

226. Loo, Y.; Wong, Y.-C.; Cai, E.Z.; Ang, C.-H.; Raju, A.; Lakshmanan, A.; Koh, A.G.; Zhou, H.J.; Lim, T.-C.; Moochhala, S.M.; et al. Ultrashort peptide nanofibrous hydrogels for the acceleration of healing of burn wounds. Biomaterials 2014, 35, 4805-4814. [CrossRef]

227. Nguyen, L.H.; Gao, M.; Lin, J.; Wu, W.; Wang, J.; Chew, S.Y. Three-dimensional aligned nanofibers-hydrogel scaffold for controlled non-viral drug/gene delivery to direct axon regeneration in spinal cord injury treatment. Sci. Rep. 2017, 7, 42212. [CrossRef]

228. An, D.; Ji, Y.; Chiu, A.; Lu, Y.-C.; Song, W.; Zhai, L.; Qi, L.; Luo, D.; Ma, M. Developing robust, hydrogel-based, nano fiber-enabled encapsulation devices (NEEDs ) for cell therapies. Biomaterials 2015, 37, 40-48. [CrossRef]

229. Jain, K.K. An Overview of Drug Delivery Systems. In Methods in Molecular Biology; Jain, K.K., Ed.; Humana Press: New York, NY, USA, 2020; Volume 2059, pp. 1-54.

230. Norouzi, M.; Shabani, I.; Ahvaz, H.H.; Soleimani, M. PLGA/gelatin hybrid nanofibrous scaffolds encapsulating EGF for skin regeneration. J. Biomed. Mater. Res. Part A 2015, 103, 2225-2235. [CrossRef]

231. Sun, Y.; Cheng, S.; Lu, W.; Wang, Y.; Zhang, P.; Yao, Q. Electrospun fibers and their application in drug controlled release, biological dressings, tissue repair, and enzyme immobilization. RSC Adv. 2019, 9, 25712-25729. [CrossRef]

232. Gao, Q.; Liu, L.; Lu, X.; Zhou, H. In situ forming hydrogels based on chitosan for drug delivery and tissue regeneration. Asian J. Pharm. Sci. 2016, 11, 673-683.

233. Sill, T.J.; von Recum, H.A. Electrospinning: Applications in drug delivery and tissue engineering. Biomaterials 2008, 29, 1989-2006. [CrossRef]

234. Torres-Martinez, E.J.; Bravo, J.M.C.; Medina, A.S.; González, G.L.P.; Gómez, L.J.V. A Summary of Electrospun Nanofibers as Drug Delivery System: Drugs Loaded and Biopolymers Used as Matrices. Curr. Drug Deliv. 2018, 15, 1360-1374. [CrossRef]

235. Chou, S.-F.; Carson, D.; Woodrow, K.A. Current strategies for sustaining drug release from electrospun nanofibers. J. Control. Release 2015, 220, 584-591. [CrossRef] [PubMed]

236. Bas, O.; De-Juan-Pardo, E.M.; Catelas, I.; Hutmacher, D.W. The quest for mechanically and biologically functional soft biomaterials via soft network composites. Adv. Drug Deliv. Rev. 2018, 132, 214-234. [CrossRef] [PubMed]

237. Lee, K.Y.; Rowley, J.A.; Eiselt, P.; Moy, E.M.; Bouhadir, K.H.; Mooney, D.J. Controlling mechanical and Swelling Properties of Alginate Hydrogels Independently by Cross-Linker Type and Cross-Linking Density. Macromolecules 2000, 33, 4291-4294. [CrossRef]

238. Su, T.; Zhao, W.; Wu, L.; Dong, W.; Qi, X. Facile fabrication of functional hydrogels consisting of pullulan and polydopamine fibers for drug delivery. Int. J. Biol. Macromol. 2020, 163, 366-374. [CrossRef] [PubMed]

239. Ghalei, S.; Nourmohammadi, J.; Solouk, A.; Mirzadeh, H. Enhanced Cellular Response Elicited by Addition of Amniotic fluid to Alginate Hydrogel-Electrospun Silk Fibroin Fibers for Potential Wound Dressing Application. Colloids Surfaces B Biointerfaces 2018, 172, 82-89. [CrossRef]

240. Jaiswal, M.; Gupta, A.; Agrawal, A.K.; Jassal, M.; Dinda, A.K.; Koul, V. Bi-Layer Composite Dressing of Gelatin Nanofibrous Mat and Poly Vinyl Alcohol Hydrogel for Drug Delivery and Wound Healing Application: In-Vitro and In-Vivo Studies. J. Biomed. Nanotechnol. 2013, 9, 1495-1508. [CrossRef]

241. Chen, Y.; Qiu, Y.; Wang, Q.; Li, D.; Hussain, T.; Ke, H.; Wei, Q. Mussel-inspired sandwich-like nanofibers/hydrogel composite with super adhesive, sustained drug release and anti-infection capacity. Chem. Eng. J. 2020, 399, 125668. [CrossRef] 